\title{
Performance Evaluation of the Banking Sector in Bangladesh: A Comparative Analysis
}

\author{
Md. Ariful Islam (Corresponding author) \\ Deputy Manager, BASIC Bank Limited
}

Khulna Branch, 107 Sir Iqbal Road, Khulna, Bangladesh

Tel: 880-171-752-9503Ｅ-mail: arifrussell@yahoo.com

Mahmudul Hasan Siddiqui

Senior Territory Manager, Unilever Bangladesh Limited

M.N. Trading \& Co, Modina Tower, Habibpur, Narayanganj, Bangladesh

Tel: 880-171-168-8592Ｅ-mail: mhs.sadi@gmail.com

\author{
Kh. Fahim Hossain \\ Accountant, Chevron Bangladesh Ltd. \\ 57 Gulshan Avenue (4th Floor), Gulshan-1, Dhaka-1212, Bangladesh \\ Tel: 880-192-666-2131Ｅ-mail: khfahim04@ gmail.com
}

Luthful Karim

Assistant Manager, BASIC Bank Limited

Khulna Branch, 107 Sir Iqbal Road, Khulna, Bangladesh

Tel: 880-191-212-5098Ｅ-mail: shajiblks@gmail.com

Received: December 7, 2013 Accepted: December 31, 2013

doi:10.5296/ber.v4i1.4672 URL: http://dx.doi.org/10.5296/ber.v4i1.4672

\begin{abstract}
Banking sector plays an important role in the economic development of a country especially
\end{abstract}


for Bangladesh, a sound and efficient banking system is one of the most important preconditions to achieve economic development. At present, a total of 47 banks (4 SCBs, 4 DFIs, 30 PCBs and 9 FCBs) having 7246 branches are operating in Bangladesh with Tk. 4411.98billion total assets and Tk. 3329.08 billion deposits. The performance of 4types of banks needs to be compared with each other as well as the overall performance of banking sector needs to be compared with other countries. Quantitative comparison can be done on the basis of CAMEL ratio. CAMEL ratios mainly indicate the adequacy of the risk based capital, non-performing loan position, expenditure-income ratio, return on assets (ROA), return on equity (ROE), net interest income (NII), writing of debt, liquid assets, excess liquidity, etc. The study compares the 4 types of bank's time series performance on the basis of selected CAMEL ratios. This thesis paper is divided into five chapters. Chapter one comprises introduction. Chapter two includes overview of banking sector of Bangladesh. Performance of banking sector is contained in chapter three. Chapter four covers analysis and interpretation. The last chapter is about findings and conclusion.

Keywords: Banking System, ROI, CAMEL, Liquidity, Performance

\section{Introduction}

\subsection{Background of the Study}

The banking industry of Bangladesh is a mixed one comprising nationalized, private and foreign commercial banks. Many efforts have been made to explain the performance of these banks. Understanding the performance of bank requires knowledge about the profitability and the relationships between variables like market size, bank's risk and bank's market size with profitability. Indeed, the performance evaluation of commercial banks is especially important today because of the fierce competition. The banking industry is experiencing major transition for the last two decades. It is becoming an imperative for banks to endure the pressure coming from both domestic and external factors and prove to be profitable. Until the early 1985, Bangladesh had a highly repressed financial sector. Banks and other financial institutions were fully owned by the government. In the early of 1980, Bangladesh entered into the IMF/ World Bank adjustment programs and the process of privatization and liberalization gained momentum under the influence of the World Bank and The IMF. Since then the banking industry of Bangladesh has become an attractive ground for both domestic and foreign investors to take part in the game. It is of the utmost important of these players to prove themselves profitable and work on those pillars of the same.

\subsection{Objectives of the Studies}

The broader objectives of the study are as under:

a. To known the banking sector and its current trends.

b. To study the category wise performance of all banks operating in Bangladesh on the basis of selected CAMEL ratio.

c. To examine the profitability of banks.

d. To analyze how the correlation of different ratios affects the net interest income of banks. 
1.3 Methodology of the Study

The research methodology of the selected topic follows in these dimensions:

\subsubsection{Population of the Study}

All the banks in Bangladeshi banking sector are divided in following groups from the year 2004 to 2011:

i) State-Owned Commercial Banks ( SCB's)

ii) Development Financial Institutions (DFI's)

iii) Private Commercial Banks (PCB's)

iv) Nine Foreign Commercial Banks (FCB's)

\subsubsection{The Period of the Study}

The study is covered for eight years from the year 2004 to 2011.

\subsubsection{Data Collection}

This study is based on secondary data. For this purpose, the researcher has used the data published in Annual reports of Bangladesh Bank and other related websites. Moreover, the journals, articles, reports and surveys have been referred.

\subsubsection{Data Analysis}

For the comparison between the groups, some statistical tests have been used according to the nature and objectives of the study. The collected information is analyzed by Anova test. The conclusions have been drawn on the basis of 5\% level of significance. Another statistical technique 'Correlation' is used to find out the impact of different ratios. Anova test is done with the help of SPSS software and correlation is done with the help of http://ncalculators.com/statistics/correlation-coefficient-calculator.htm website.

\subsection{Variables}

To analyze the financial performance of banking sector different variables are included in this study, they are as follow:

\section{a. Deposits}

Deposits are considered as banks' main source of funding and are the lowest cost of funds. The more deposits are transformed into loans, the higher the interest margin and profit. Hence, deposits generally have positive impact on profitability of the banks. But if a bank can't transform its deposits into loans efficiently it may bring negative impact on profitability also.

\section{b. Capital Adequacy (C)}

Capital adequacy is a measure of the financial strength of a bank, usually express as a ratio of its shareholders ${ }^{\text {ee }}$ fund to total assets. The ratio reflects the ability of a bank to withstand the unanticipated losses. This ratio has a positive relationship with the financial soundness of the bank. 
c. Asset Quality (A)

Asset quality is an important measure of the strength of banks. The ratio of non-performing loans and advances as a share of total and advances is considered for the purpose of analysis. In addition, the ratio of total loans and advances to total assets is utilized to measure the extent of deployment of assets in earning assets.

d. Management Quality (M)

The capacity/efficiency of the management of a bank can be measured with the help of certain ratios. To capture the possible dynamics of management efficiency, the following ratios are considered: total loans and advances to total deposits, interest expenses to total deposits, and operating expenses to total assets.

e) Earnings Ability (E)

Two ratios are used to assess the earnings ability of the banks under study. The first ratio is the net income to total assets or "ROA". The second ratio used is interest income to total assets. The two ratios have positive relationship with the financial performance of the bank and negative relationship the risk of bank failure.

f) Liquidity (L)

Two ratios are employed in this study to assess the liquidity level of the banks. The first one is total liquid assets to total assets. The second ratio is liquid assets to customerse deposits.

\subsection{Hypothesis}

The broader hypotheses are as under

A) $\mathrm{Ho}=$ There is no significant difference in total deposits among all the banking groups. $\mathrm{H} 1=$ There is significant difference in total deposits among all the banking groups.

B) $\mathrm{Ho}=$ There is no significant difference in Capital adequacy ratio among all the banking groups.

$\mathrm{H} 1=$ There is significant difference in Capital adequacy ratio among all the banking groups.

C) $\mathrm{Ho}=$ There is no significant different in Non Performing Loans to total loans ratios among all the four banking groups during 2004 to 2011.

$\mathrm{H} 1=$ There is significant different in Non Performing Loans to total loans ratios among all the four banking groups during 2004 to 2011.

D) $\mathrm{Ho}=$ There is no significant different in Ratio of net Non Performing Loans to total loans ratios among all the four banking groups.

$\mathrm{H} 1=$ There is significant different in Ratio of net Non Performing Loans to total loans ratios among all the four banking groups.

E) $\mathrm{Ho}=$ There is no significant different regarding Bad debts among all the four banking groups.

$\mathrm{H} 1=$ There is significant different regarding Bad debts among all the four banking groups. 
F) $\mathrm{Ho}=$ There is no significant different regarding Expenditure-income among all the four banking groups.

$\mathrm{H} 1=$ There is significant different regarding Expenditure-income among all the four banking groups.

G) $\mathrm{Ho}=$ There is no significant difference regarding Return on Assets in $\%$ among all the four banking groups.

$\mathrm{H} 1=$ There is significant difference regarding Return on Assets in $\%$ among all the four banking groups.

H) $\mathrm{Ho}=$ There is no significant difference regarding Return on equity among all the four banking groups.

$\mathrm{H} 1=$ There is significant difference regarding Return on equity among all the four banking groups.

I) $\mathrm{Ho}=$ There is no significant difference regarding net interest income ratio among all the four banking groups during 2004 to 2011.

$\mathrm{H} 1=$ There is significant difference regarding net interest income ratio among all the four banking groups during 2004 to 2011.

J) $\mathrm{Ho}=$ There is no significant difference regarding liquid assets ratio among all the four banking groups during 2004 to 2011.

$\mathrm{H} 1=$ There is significant difference regarding liquid assets ratio among all the four banking groups during 2004 to 2011.

$\mathrm{K}) \mathrm{Ho}=$ There is no significant difference regarding Excess Liquidity ratio among all the four banking groups during 2004 to 2011.

$\mathrm{H} 1=$ There is significant difference regarding Excess Liquidity ratio among all the four banking groups during 2004 to 2011.

\subsection{Limitation of the Study}

The study of this kind is generally encountered with some limitations. Unavailability of data is a major problem. Data accuracy cannot be ensured as mainly secondary data collected from Annual Report, Various Financial Stability reports, Economic trends is used in this study. However, repeated and sincere efforts have been given to ensure the accuracy of the data used in this study.

\subsection{Literature Review}

With respect to the Performances of Bangladeshi Banking sector, foreign and national experts undertook number of studies.

Pandey (2006) stated that the easiest way to evaluate the performance of a firm is to compare its present ratio with the past ratio. It gives an indicator of the direction of change and reflects whether the firm's financial performance has improved, deteriorated or remained constant over time.

Chowdhury and Ahmed (2009) observed that all the selected private commercial banks are able to achieve a stable growth of branches, employee, deposit, loans and advances, net income, earning per share during the period of 2002-2006. They indicate that the prospect of private 
commercial banks in Bangladesh is very bright.

Chowdhury (2002) observed that the banking industry of Bangladesh is a mixed one comprising nationalized, Private and foreign banks. Many efforts have been made to explain the performance of these banks. Understanding the performance of the bank requires knowledge about the profitability and the relationship between variables like market size, banks risk and banks market size with the profitability.

Chowdhury and Islam (2007) stated that deposit and loan advances of nationalized commercial banks (NCBs) are less sensitive to interest changes than those of Specialized Banks (SBs). So, SBs should not make abrupt change in lending or deposit by following the NCBs. If NCBs change their lending rate, their deposit or loan and advances will be affected less than those of CBs. Moreover, deposits of NCBs have higher volume and higher volatility than those of SBs. However SBs offer higher deposit rates and charge higher lending rate than NCBs, which is why the interest rate spread of SBs was higher than that of NCBs.

Siddique and Islam (2001) pointed out that the commercial banks, as a whole are performing well and contributing to the economic development of the country. The average profitability of all Bangladeshi Banks collectively was $0.09 \%$ during 1980 to 1995 which means that a profit of Tk.0.09 was earned by utilizing assets of Tk.100 in every aspect of profit; banking sector contributes the national economy as well as the individual organization. Despite overall growth of the banking sector positive the performance of different categories of banks were not equally attractive.

Mujeri \& Younus (2009) stated that the higher the non interest income as a ratio of total assets of banks the lower interest rate spread. Similarly market share of deposit of a bank, statutory reserve requirement and NSD certificate interest rate affects the IRS. The analysis in terms of banks group shows that IRS is significantly influenced by operating cost and classified loan of state owned commercial bank and specialized banks while inflation, operating cost market share of deposit, statutory reserve requirement and taxes are important for the private commercial banks. On the other hand non interest income, inflation, market share and taxes matter for the foreign Commercial banks.

Khan (2008) stated that bank is evaluated based on profit and loss as the same way for other business. If the shareholders of the bank get more profit then the bank is identified as successful. Banks can attain success if relevant risks are effectively controlled.

Van Horne \& Wachowicz (2005) stated that to evaluate a firm's financial condition and performance the financial analyst need to perform "checkups" on various aspects of a firm's financial health. A tool frequently used these checkup is a financial ratio.

\section{Overview of Banking Sector in Bangladesh}

\subsection{Financial System in Bangladesh}

Financial System is the set of well organized institutional set up which helps to transfer excess funds from surplus unit to deficit unit. The financial system in Bangladesh includes Bangladesh Bank (the Central Bank), scheduled banks, and non-bank financial institutions like 


\section{Macrothink}

leasing etc, Microfinance institutions (MFIs), insurance companies, co-operative banks, credit rating agencies and stock exchange. Banking sector occupies the lion portion share of financial system in Bangladesh. Bangladesh bank is authorized for regulating and supervising financial institutions in Bangladesh.

\subsection{Banking sector in Bangladesh}

Despite in recent years, many non-bank financial institution has been established, still the financial system of Bangladesh is mainly banking sector based. Banking sector consists of Bangladesh Bank as the central bank, four state-owned commercial banks, four specialized bank/development financial institutions, thirty private commercial banks and nine foreign commercial banks.

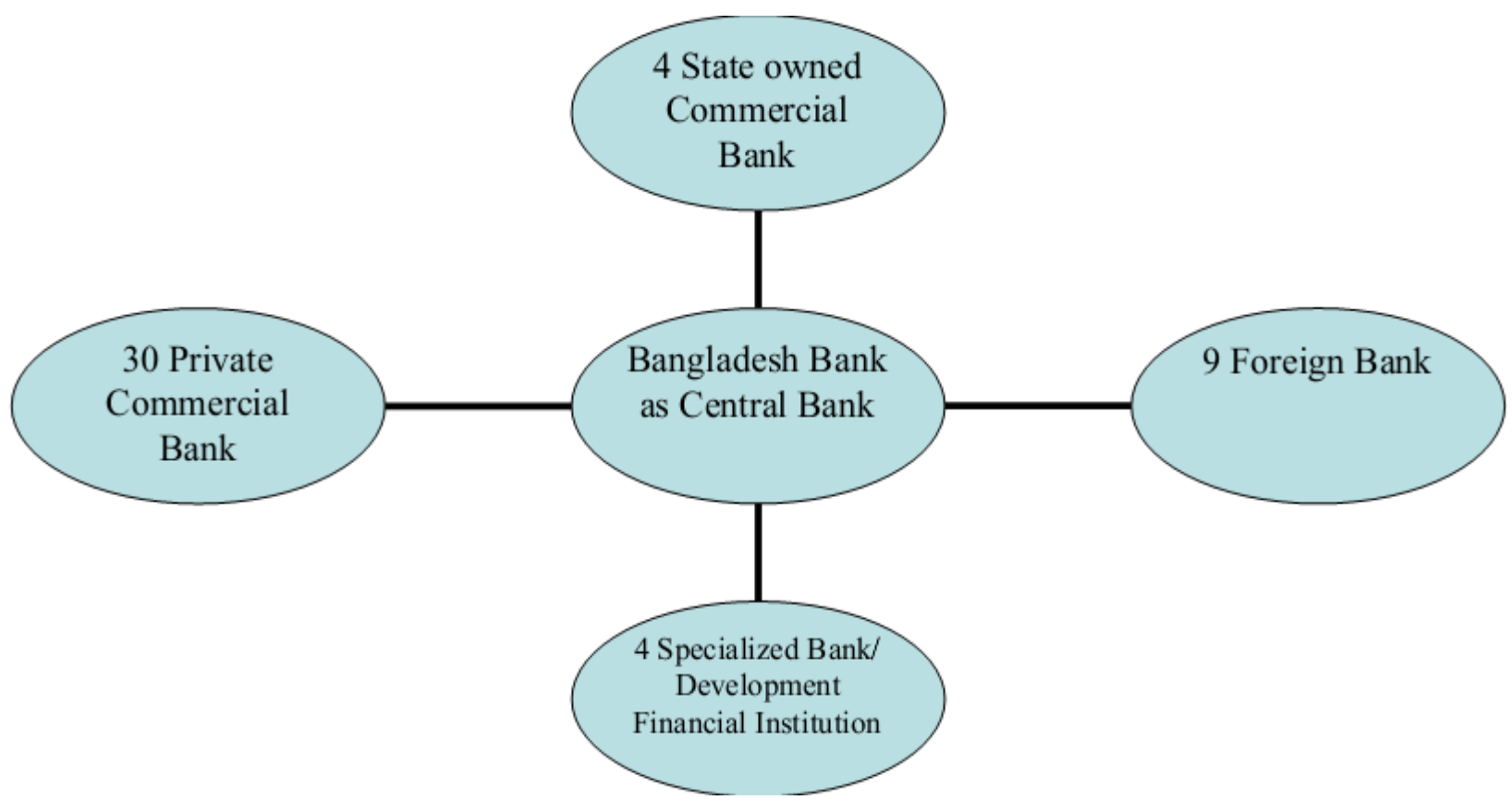

Banking sector in Bangladesh

\subsection{Bangladesh Bank}

Bangladesh Bank, the central bank and main regulatory body for the country's financial system and monetary system, was established in Dhaka as an independent organization according to the Bangladesh Bank Order, 1972 (P.O. No. 127 of 1972) with was effective from 16th December, 1971 [Bangladesh Bank website]. Now, it has nine offices located at different division of the country among which two in Capital city namely Motijheel and Sadarghat, two in Rajshahi division namely Bogra and Rajshahi and one is each of the rest five divisions namely Chittagong, Khulna, Sylhet, Barisal and Rangpur.

\subsection{Functions of Bangladesh Bank}

Bangladesh Bank basically responsible for all the core functions that are done by all the monetary and financial sector regulators. Besides the core functions, Bangladesh Bank is also responsible for some other supporting functions. The functions of Bangladesh Bank are cited in below: 
- To formulate and implement monetary and credit policies.

- To regulate and supervise and monitor financial intermediaries like banks and non-bank financial institutions.

- Currency issuance and circulation across the country.

- Payment system management.

- Holder and manager of FX reserve of the country.

- Bankers to the Government.

- To prevent money laundering.

- To implement Foreign exchange regulation Act.

- Preserve all credit information.

Besides this function, Bangladesh Bank also responsible for asset classification, loan concentration, setting up single borrower exposure limit, Licensing to the new bank and branch, impose penalty for non-compliances, intervention in the management for assistance if any bank face difficulties, prepare guidelines and issuance directives regarding banking operation, guidelines for core risk management, publication of different economic review etc.

Bangladesh bank monitors the performance of all schedule banks operating in the country through CAMEL rating system. The ratio used in CAMEL rating system reflects the performance. Based on this CAMEL rating performance analysis, Bangladesh Bank undertakes necessary initiatives. For this purpose, Bangladesh Bank depends mostly on historic data. Bangladesh Bank also introduced the risk based inspection system for the supervision of schedule banks. In a report of IMF 2010, it is stated that the supervision of commercial banks is still compliance based to see whether policy and procedures are followed for which it has to primarily rely on checklist and it lacks proper forward-looking qualitative judgment [IMF, 2010].

\subsection{History of Scheduled/Commercial Bank}

\subsubsection{State-Owned Commercial Bank}

Bangladesh becomes independent after long nine months war. Before the liberation, most of the banking company were owned by the then west Pakistanis. So, the then Government of Bangladesh nationalized all the banks operating in Bangladesh except foreign Banks (Incorporated in abroad). All these banks were grouped into commercial banks through merger process. Among the six commercial banks, two banks namely Pubali bank and Uttara bank were shifted to private sector in January, 1985 and another bank Rupali bank was incorporated as public limited company with effect from December, 1986. The rest three banks namely Sonali bank, Agrani bank and Janata bank were also transferred as public limited company in 2007. So, now there are four state owned commercial banks operating in Bangladesh.

In a report of IMF, it has been stated that the initial focus on state-led banking imitate the Government's lively quest of industrial policies to inspire growth. SCBs were considered as the proper means of generating savings that could be facilitate industrial finance to the sectors of the economy with the best growth prospects. SCBs major drawbacks are the lack of corporate governance and undue political pressure even in loan disbursements without proper 
analyzing the prospects of the borrower. Despite recently some measures have been undertaken but this legacy is still visible in high NPL ratios and frail solvency. The Government of Bangladesh has indicated its desire to divest of the state owned banks, and took an initiative in late 2008 to make them limited liability companies. The Ministry of Finance, in consultation with the SEC and BB allowed the banks to move their accumulated losses into capital surpluses based on the notion of Goodwill. The accumulated losses were converted in a Goodwill asset that will be amortized out of future profits. This accounting treatment is questionable and concerns remain regarding the true financial condition of these banks [IMF, 2010].

\subsubsection{Specialized Bank/Development Financial Institutions (DFIs)}

After liberation, two specialized bank operating in Bangladesh were also nationalized and renamed as Bangladesh Krishi Bank and Bangladesh Shilpa Bank. But Bangladesh Krishi bank was divided in 1987 and renamed as Rajshahi Krishi Unnayan Bank (RAKUB) for Rajshahi Division to promote agricultural development in that region and Bangladesh Krishi bank for the rest of part of the country. In 1988, another specialized bank name Bank of Small Industries and Commerce Bangladesh Ltd. (BASIC) was established as private bank to promote small and medium entrepreneurship. In 1993, the then Government of Bangladesh took the control of BASIC and was declared it as a specialized bank. Bangladesh Shilpa Bank was merged with Bangladesh Shilpa Rin Sangsta (BSRS) in 2010 and renamed as Bangladesh Development Bank Limited (BDBL).

So, currently there are four specialized banks which are termed as Development Financial Institutions (DFIs) operating in Bangladesh.

\subsubsection{Private Commercial Bank}

Local private commercial bank started operation in the decades of 1980's. We can categorize local private bank in the following manner:

- First generation bank: Those established in the decades of 1980s.

- Second generation bank: These banks started operation in 1990 to 1995.

- Third generation bank: After 1998, these banks are established.

At present, there are thirty local private commercial banks operating in Bangladesh. PCBs dominate the banking sector of Bangladesh. More than fifty percent of total deposits and assets are covered by the PCBs. The performance of PCBs is much better than SCBs and DFIs in all respects. Client service innovation and banking service automation is one of the major reasons for their domination over the SCBs and PCBs. among the three generation of PCBs, third generation banks are more innovative and provide better client services through automation whereas first generation banks are little bit in backward position though they continuously improving their condition to compete in the market.

Bangladesh's PCBs have quickly occupy market share at the expense of the state-owned commercial banks (SCB) and presently grasp more than 59 percent of total deposits whereas it is only 28 percent for the SCBs and PCBs assets coverage is 58\% whereas it is only $29 \%$ in SCBs. 


\subsubsection{Foreign Commercial Banks (FCBs)}

Before liberation, there were few FCBs operating in the country which was incorporated in abroad. Among those foreign banks, Standard chartered Grindlays Bank was merged with Standard Chartered Bank in 2003 and then American Express Bank further merged with Standard Chartered Bank in 2005. Credit Agricole Indosuez bank was renamed as Commercial Bank of Ceylon Ltd. in 2003. Currently, there are nine foreign commercial banks operating in Bangladesh. Foreign Commercial Banks suffered for lack of wide spread branch network. Their operation is basically limited to capital city and some other municipal city corporation area.

\subsection{Scheduled Bank According to the Law}

According to Bank Company Act, 2007, "All such banks operating in Bangladesh with different paid-up capital and reserves having a minimum of an aggregate value of Tk. 50 lacs and conducting their affairs to the satisfaction of the Bangladesh Bank have been declared as scheduled banks in terms of section 37(2) of Bangladesh Bank Order 1972. In terms of section 13 of Bank Company Act, 1991, the minimum aggregate value was Tk. 20 crores. From 30th March, 2003, it was tk. 100 crores and from the 8th October 13, 2007, it has been raised at the minimum of Tk. 200 crores" [Bank Company Act, 2007].

\section{Performance Evaluation of Banking Sector}

The concept of financial performance and research into its measurement is well advanced within finance and management fields. Recently a well-judged technique named CAMEL rating is widely used for evaluating performance of financial institutions, especially to banks. In Bangladesh bank as a Central bank, which is regulatory body has been calculating this rating till now. Performance of the banking sector under CAMEL frame work, which involves analysis and evaluation of the five crucial dimensions of banking operations.

We now evaluate the performance of banks on the basis of CAMEL framework. This evaluation is done for the four categories of banks, namely "state-owned commercial banks (SCBs), government-owned development financial institutions (DFIs), domestic private commercial banks (PCBs), and foreign commercial banks (FCBs)".

a) Capital Adequacy (C)

Capital adequacy is a measure of the financial strength of a bank, usually express as a ratio of its shareholders' fund to total assets. The ratio reflects the ability of a bank to withstand the unanticipated losses. This ratio has a positive relationship with the financial soundness of the bank.

\section{b) Asset Quality (A)}

Asset quality is an important measure of the strength of banks. The ratio of non-performing loans and advances as a share of total and advances is considered for the purpose of analysis. In addition, the ratio of total loans and advances to total assets is utilized to measure the extent of deployment of assets in earning assets. 
c) Management Quality (M)

The capacity/efficiency of the management of a bank can be measured with the help of certain ratios. To capture the possible dynamics of management efficiency, the following ratios are considered: total loans and advances to total deposits, interest expenses to total deposits, and operating expenses to total assets.

d) Earnings Ability (E)

Two ratios are used to assess the earnings ability of the banks under study. The first ratio is the net income to total assets or "ROA". The second ratio used is interest income to total assets. The two ratios have positive relationship with the financial performance of the bank and negative relationship the risk of bank failure.

e) Liquidity (L)

Two ratios are employed in this study to assess the liquidity level of the banks. The first one is total liquid assets to total assets. The second ratio is liquid assets to customers ${ }^{e e}$ deposits.

\subsection{Banking System Structure}

\begin{tabular}{|c|c|c|c|c|c|c|}
\hline \multirow{2}{*}{$\begin{array}{c}\text { Bank } \\
\text { types }\end{array}$} & \multicolumn{7}{|c|}{2012 (June) } \\
\cline { 2 - 7 } & $\begin{array}{c}\text { Number } \\
\text { of banks }\end{array}$ & $\begin{array}{c}\text { Number } \\
\text { of branches }\end{array}$ & $\begin{array}{c}\text { Total } \\
\text { assets }\end{array}$ & $\begin{array}{c}\text { \% of industry } \\
\text { assets }\end{array}$ & Deposits & $\begin{array}{c}\text { \% of } \\
\text { deposits }\end{array}$ \\
\hline SCBs & 4 & 3449 & 1771.75 & 27.2 & 1305.02 & 26.5 \\
\hline DFls & 4 & 1417 & 368.84 & 5.7 & 243.39 & 4.9 \\
\hline PCBs & 30 & 3130 & 3965.93 & 60.8 & 3092.86 & 62.6 \\
\hline FCBs & 9 & 63 & 414.63 & 6.3 & 295.93 & 6.00 \\
\hline Total & $\mathbf{4 7}$ & $\mathbf{8 0 5 9}$ & $\mathbf{6 5 2 1 . 1 6}$ & $\mathbf{1 0 0 . 0}$ & $\mathbf{4 9 3 7 . 2 1}$ & 100 \\
\hline
\end{tabular}

Source: Bangladesh Bank Annual Reports

The banking sector of Bangladesh comprises four categories of scheduled banks. These are the state owned commercial banks (SCBs), the state owned development financial institutions (DFIs), the private commercial banks (PCBs), and the foreign commercial banks (FCBs). While the number of banks remained unchanged at 47 in 2011, the number of bank branches increased from 7658 in 2010 to 7961 in 2011 reflecting the opening of new branches by the PCBs. At the end of June 2012, the total number of bank branches increased further to 8059 , with total number of banks remaining unchanged at 47 . The structure of the banking sector with breakdown by type of banks is shown in the Table above.

\subsection{Deposits}

Deposits are considered as banks' main source of funding and are the lowest cost of funds. The more deposits are transformed into loans, the higher the interest margin and profit. Hence, deposits generally have positive impact on profitability of the banks. But if a bank can't 
transform its deposits into loans efficiently it may bring negative impact on profitability also.

Table 1. Total Deposits by Types of Banks (Taka in Billion)

\begin{tabular}{|l|l|l|l|l|l|l|l|l|}
\hline Banks Types & 2004 & 2005 & 2006 & 2007 & 2008 & 2009 & 2010 & 2011 \\
\hline SCB's & 544.56 & 608.36 & 641.16 & 686.76 & 745.86 & 869.19 & 1044.96 & 1235.65 \\
\hline DFI's & 75.10 & 89.50 & 100.20 & 115.60 & 137.80 & 161.10 & 183.4 & 214.40 \\
\hline PCB's & 588.00 & 731.30 & 955.50 & 1150.20 & 1450.70 & 1792.40 & 2266.50 & 2787.5 \\
\hline FCB's & 108.44 & 125.54 & 163.74 & 196.34 & 226.70 & 227.6 & 239.7 & 284.8 \\
\hline Total & 1326.1 & 1554.7 & 1860.6 & 2148.90 & 2561.06 & 3050.29 & 3734.56 & 4522.35 \\
\hline
\end{tabular}

Source: Bangladesh Bank Annual Reports (2004-2011)

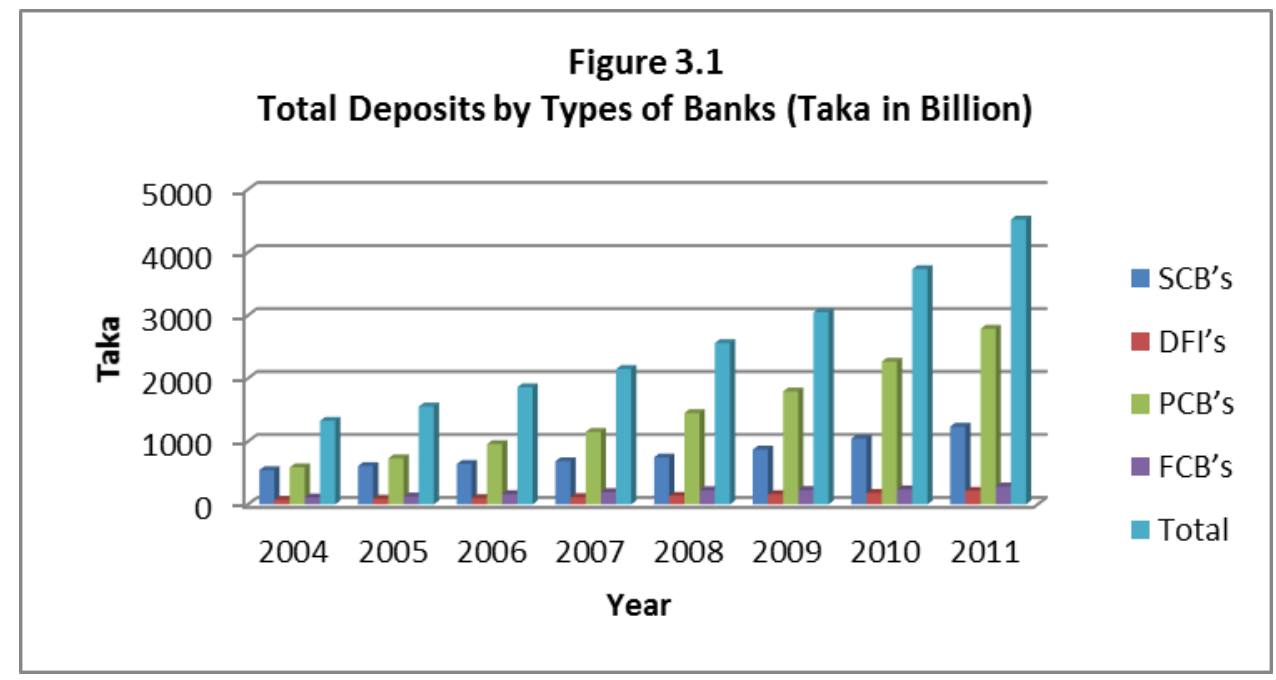

Source: Bangladesh Bank Annual Reports (2004-2011)

Table 2. Market Share of Deposits by Types of Banks (percent)

\begin{tabular}{|l|r|r|r|l|l|l|l|l|}
\hline Banks Types & \multicolumn{1}{|c|}{2004} & \multicolumn{1}{|c|}{2005} & 2006 & 2007 & 2008 & 2009 & 2010 & 2011 \\
\hline SCB's & $41.38 \%$ & $39.13 \%$ & $34.46 \%$ & $31.96 \%$ & $29.12 \%$ & $28.49 \%$ & $28.08 \%$ & $27.40 \%$ \\
\hline DFI's & $5.71 \%$ & $5.76 \%$ & $5.39 \%$ & $5.38 \%$ & $5.38 \%$ & $5.28 \%$ & $4.93 \%$ & $4.75 \%$ \\
\hline PCB's & $44.68 \%$ & $47.04 \%$ & $51.35 \%$ & $53.53 \%$ & $56.64 \%$ & $58.76 \%$ & $60.90 \%$ & $61.81 \%$ \\
\hline FCB's & $8.24 \%$ & $8.07 \%$ & $8.80 \%$ & $9.14 \%$ & $8.86 \%$ & $7.47 \%$ & $6.10 \%$ & $6.03 \%$ \\
\hline Total & $100 \%$ & $100 \%$ & $100 \%$ & $100 \%$ & $100 \%$ & $100 \%$ & $100 \%$ & $100 \%$ \\
\hline
\end{tabular}

Source: Bangladesh Bank Annual Reports(2004-2011) 


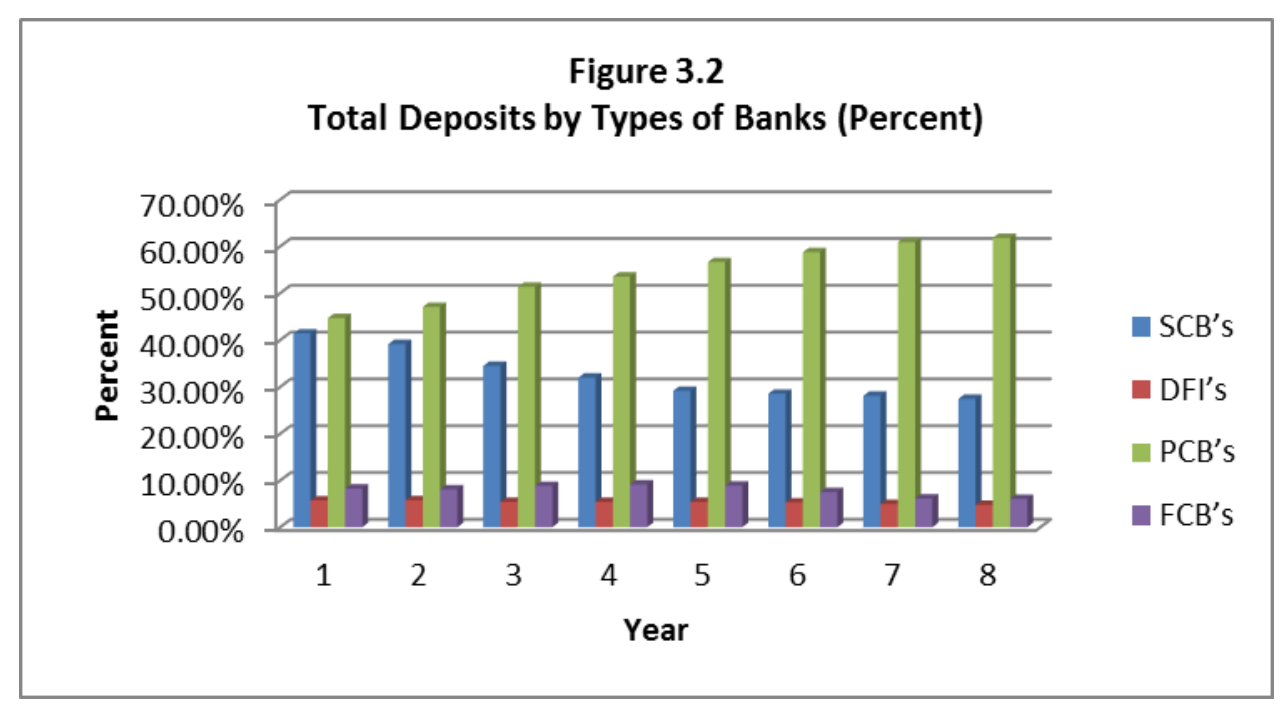

Source: Bangladesh Bank Annual Reports(2004-2011)

Total deposits of the banks in 2011 rose to Taka 4509.7 billion from Taka 3721.9 billion in 2010 showing an overall increase of 21.2 percent. The SCBs' (comprising the largest 4 banks) share in deposits decreased from 28.1 percent in 2010 to 27.4 percent in 2011. The PCBs' deposits in 2011 amounted to Taka 2787.5 billion or 61.8 percent of the total industry deposits against Taka 2266.5 billion or 60.9 percent in 2010. The FCBs' deposits in 2011 rose by Taka 45.1 billion over the year. The DFIs' deposits in 2011 were Taka 214.4 billion against Taka 183.4 billion in 2010 showing an increase of 16.9 percent over the year.

Table 3. Growth of Deposits by Types of Banks (percent

\begin{tabular}{|l|l|l|l|l|l|l|l|l|}
\hline $\begin{array}{l}\text { Banks } \\
\text { Types }\end{array}$ & 2005 & 2006 & 2007 & 2008 & 2009 & 2010 & 2011 & $\begin{array}{c}\text { Average rate of } \\
\text { Growth }\end{array}$ \\
\hline SCB's & $11.72 \%$ & $5.39 \%$ & $7.11 \%$ & $8.61 \%$ & $16.54 \%$ & $20.22 \%$ & $18.25 \%$ & $12.55 \%$ \\
\hline DFI's & $19.17 \%$ & $11.96 \%$ & $15.37 \%$ & $19.20 \%$ & $16.91 \%$ & $13.84 \%$ & $16.90 \%$ & $16.19 \%$ \\
\hline PCB's & $24.37 \%$ & $30.66 \%$ & $20.38 \%$ & $26.13 \%$ & $23.55 \%$ & $26.45 \%$ & $22.99 \%$ & $24.93 \%$ \\
\hline FCB's & $15.77 \%$ & $30.43 \%$ & $19.91 \%$ & $15.46 \%$ & $0.40 \%$ & $5.32 \%$ & $18.82 \%$ & $15.16 \%$ \\
\hline
\end{tabular}

Source: Bangladesh Bank Annual Reports(2004-2011) 


\section{Average rate of Deposits Growth by Types of Banks (percent) \\ Figure 3.3}

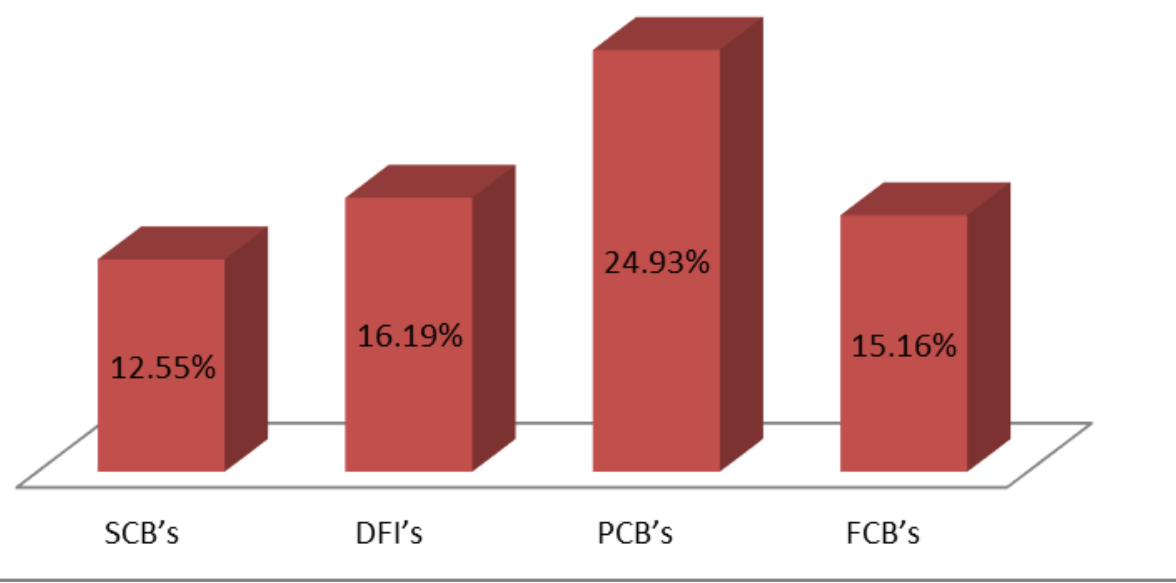

Source: Bangladesh Bank Annual Reports(2004-2011)

PCB's have the highest deposit growth rate $24.93 \%$ over last eight years while SCB's lowest $12.55 \%$ deposit growth rate. FCB's and DFI's deposit growth rate is $15.16 \%$ and $16.19 \%$ respectively over the years 2004 to 2011.

\subsection{Performance of the Types of Banks Based on Different Components of CAMEL}

CAMEL is used to measure overall performance of the banking system as well as to find out strength and weakness which ensures the safety and soundness of banking company. Performance of the types of banks regarding different components of CAMEL has been analyzed here in after. Financial indicators used are summarized in Table.

Table 4. Noted that these indicators are considered according to the CAMEL.

\begin{tabular}{|l|l|}
\hline \multicolumn{1}{|c|}{ Key Indicator } & \multicolumn{1}{c|}{ Indicators } \\
\hline Capital Adequacy & Capital to Risk Weighted Assets Ratio \\
\hline Assets Quality & Non-performing Loan Rate \\
\hline Management soundness & Expenditure-Income Ratio \\
\hline \multirow{2}{*}{ Earning performance } & Return on Assets \\
\cline { 2 - 2 } & Return on Equity \\
\cline { 2 - 2 } & Net Interset Income \\
\hline \multirow{2}{*}{ Liquidity } & Liquid Assets/Deposit Ratio \\
\cline { 2 - 2 } & Excess Liquidity/Deposit Ratio \\
\hline
\end{tabular}

Financial Indicators to Evaluate Bank Performance

\subsubsection{Capital Adequacy}

Capital adequacy focuses on the total position of banks' capital and the protection of depositors and other creditors from the potential shocks of losses that a bank might incur. It helps absorbing all possible financial risks like credit risk, market risk, operational risk, residual risk, core risks, credit concentration risk, interest rate risk, liquidity risk, reputation risk, settlement risk, strategic risk, environmental \& climate change risk etc. Under Basel-II, banks in 
Bangladesh were instructed to maintain the Minimum Capital Requirement (MCR) at 10.0 percent of the Risk Weighted Assets (RWA) or Taka 4.0 billion as capital, whichever is higher, with effect from July-September quarter in 2011. MCR was revised to increase the shock resilient capacity of the bank. However, for the fourth quarter of 2011 MCR was lowered to 9.0 percent of RWA or Taka 2.0 billion, whichever is higher.

Under the Supervisory Review Process (SRP), banks are directed to maintain a level of "adequate" capital which is higher than the minimum required capital and sufficient to cover for all possible risks in their business. This higher level of capital for the banks is usually determined and finalized through SRP-SREP dialogue.

\subsubsection{Capital to risk weighted assets ratio}

Table 5. Capital to risk weighted assets ratio by Types of Banks (percent)

\begin{tabular}{|l|l|l|l|l|l|l|l|l|}
\hline Banks Types & 2004 & 2005 & 2006 & 2007 & 2008 & 2009 & 2010 & 2011 \\
\hline SCB's & 4.1 & -0.4 & 1.1 & 7.96 & 6.9 & 9.0 & 8.9 & 11.7 \\
\hline DFI's & 9.1 & -7.5 & -6.7 & -5.5 & -5.3 & 0.4 & -7.3 & -4.5 \\
\hline PCB's & 10.3 & 9.1 & 9.8 & 10.6 & 11.4 & 12.1 & 10.1 & 11.5 \\
\hline FCB's & 24.2 & 26.0 & 22.7 & 22.7 & 24.0 & 28.1 & 15.6 & 21.0 \\
\hline Total & 8.7 & 5.6 & 6.7 & 9.6 & 10.1 & 11.6 & 9.3 & 11.4 \\
\hline
\end{tabular}

Source: Bangladesh Bank Annual Reports (2004-2011)

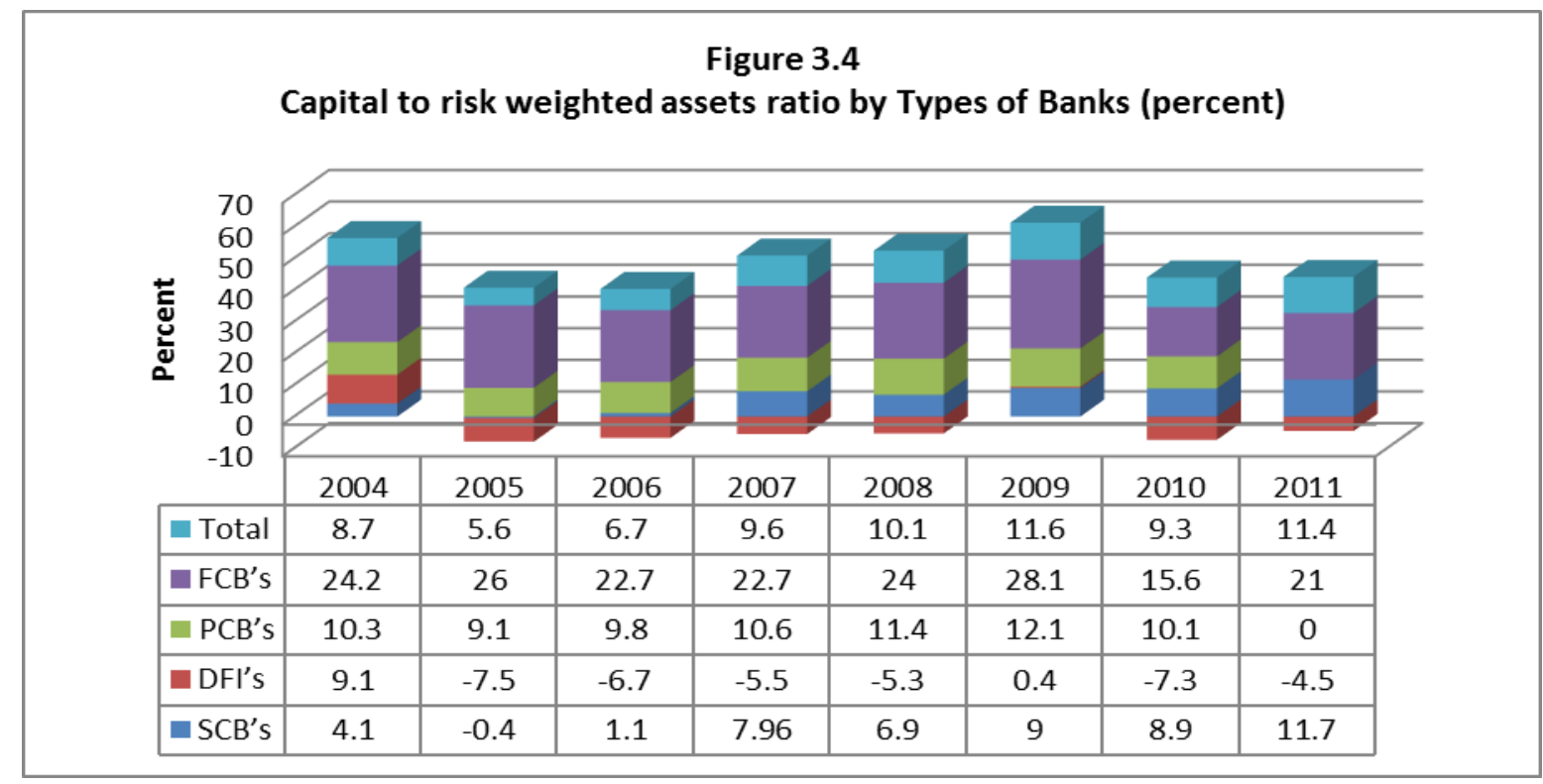

Source: Bangladesh Bank Annual Reports (2004-2011)

Table 5 shows that on 31 December 2011 in aggregate the SCBs, DFIs, PCBs and FCBs maintained CAR of 11.7, -4.5, 11.5 and 21.0 percent respectively. But individually, 3 PCBs and 2 DFIs did not maintain the minimum required CAR. Whereas, all PCBs and FCBs complied with the minimum required capital. The CAR for the banking industry as a whole was 11.4 percent at end of 2011 as against 9.3 percent at end of 2010. 


\subsubsection{Assets Quality}

The most important indicator of bank asset quality in the loan portfolio is the ratio of gross non-performing loans (NPLs) to total loans and the ratio of net NPLs to net total loans.

\subsubsection{NPL to Total Loans Ratio}

Table 6. NPLs to total loans ratios by Types of Banks (percent)

\begin{tabular}{|l|l|l|l|l|l|l|l|l|}
\hline Banks Types & 2004 & 2005 & 2006 & 2007 & 2008 & 2009 & 2010 & 2011 \\
\hline SCB's & 25.3 & 21.4 & 22.9 & 29.9 & 25.4 & 21.4 & 15.7 & 11.3 \\
\hline DFI's & 42.9 & 34.9 & 33.7 & 28.6 & 25.5 & 25.9 & 24.2 & 24.6 \\
\hline PCB's & 8.5 & 5.6 & 5.5 & 5.0 & 4.4 & 3.9 & 3.2 & 2.9 \\
\hline FCB's & 1.5 & 1.3 & 0.8 & 1.4 & 1.9 & 2.3 & 3.0 & 2.9 \\
\hline Total & 17.6 & 13.6 & 13.2 & 13.2 & 10.8 & 9.2 & 7.3 & 6.1 \\
\hline
\end{tabular}

Source: Bangladesh Bank Annual Reports (2004-2011)

In 2011, the FCBs and the PCBs had the lowest and the DFIs had the highest ratio of gross NPLs to total loans. The SCBs had a gross NPLs ratio of 11.3 percent whereas in case of the PCBs, the FCBs and the DFIs, the ratios were 2.9, 2.9 and 24.6 percent respectively, at the end of December 2011. The trend is shown in below:

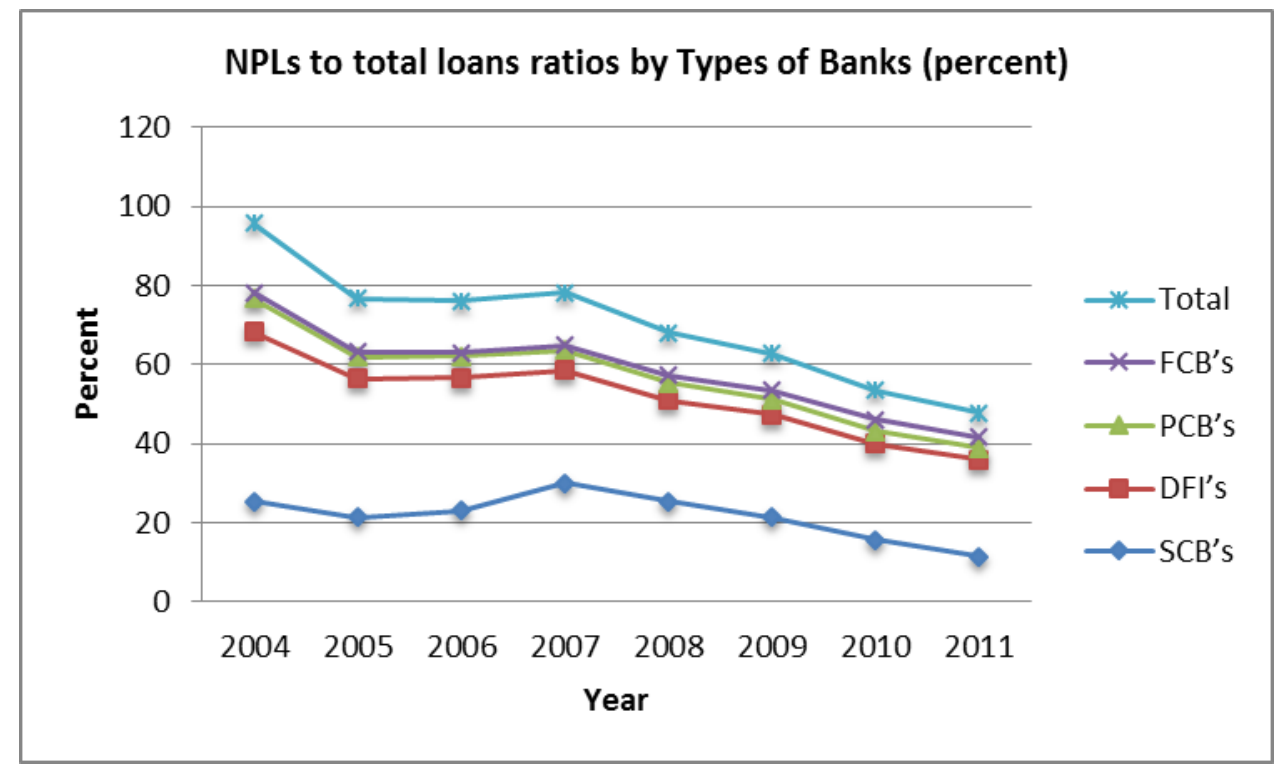

Source: Bangladesh Bank Annual Reports (2004-2011)

\subsubsection{Ratio of net NPL to total loans}

Table 7. Ratio of net NPL to total loans by Types of Banks (percent)

\begin{tabular}{|l|l|l|l|l|l|l|l|l|}
\hline Banks Types & 2004 & 2995 & 2006 & 2007 & 2008 & 2009 & 2010 & 2011 \\
\hline SCB's & 17.6 & 13.2 & 14.5 & 12.9 & 5.9 & 1.9 & 1.9 & -0.34 \\
\hline DFI's & 23.0 & 22.6 & 23.6 & 19.0 & 17.0 & 18.3 & 16.0 & 16.9 \\
\hline PCB's & 3.4 & 1.8 & 1.8 & 1.4 & .9 & .5 & 0.0 & -0.20 \\
\hline FCB's & -1.5 & -2.2 & -2.6 & -1.9 & -2.0 & -2.3 & -1.7 & -1.8 \\
\hline Total & 9.8 & 7.2 & 7.1 & 5.1 & 2.8 & 1.7 & 1.3 & 0.70 \\
\hline
\end{tabular}


Source: Bangladesh Bank Annual Reports (2004-2011)

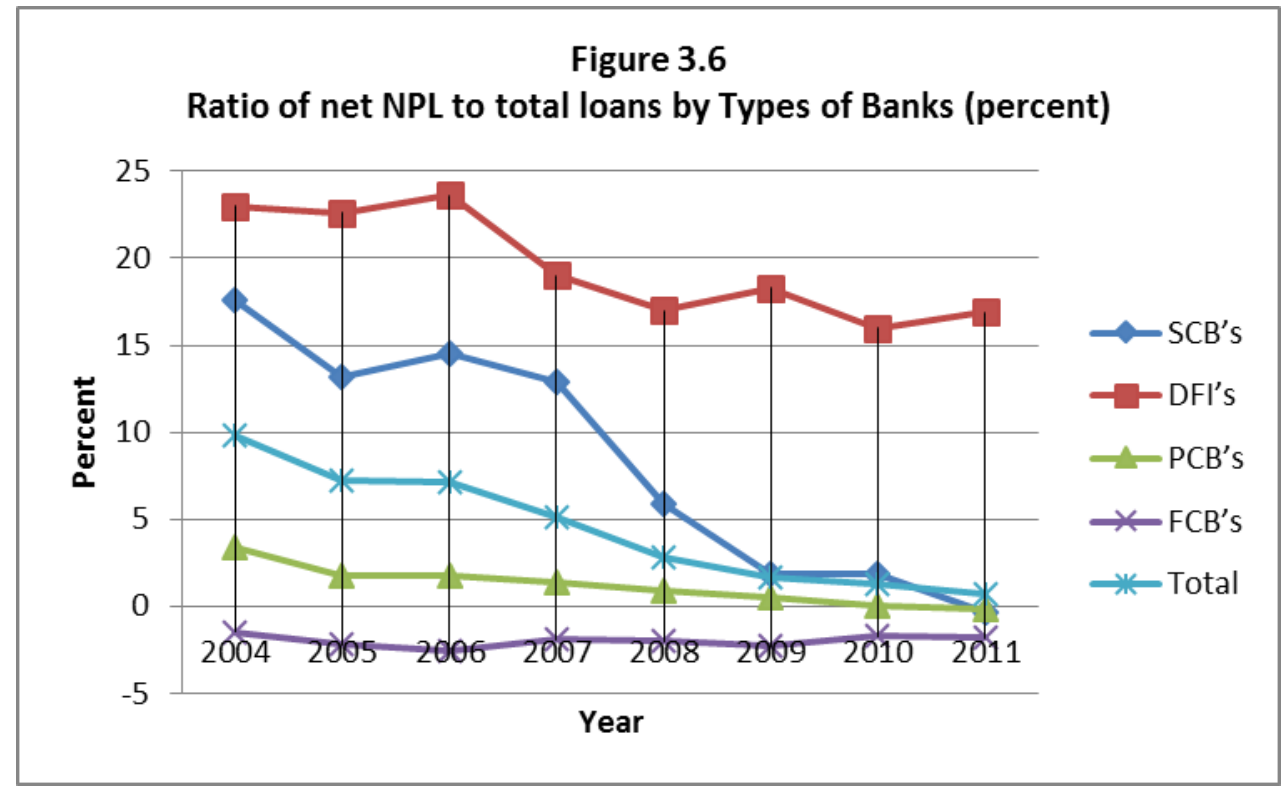

Source: Bangladesh Bank Annual Reports (2004-2011)

Table 7 and Figure 3.6 present the ratio of the net NPLs (net of provisions and interest suspense) to net total loans (net of provisions and interest suspense). It reveals from the table that the DFIs' non-performing portfolios were still high after adjustment of actual provision and interest suspense, whereas the SCBs, the FCBs and the PCBs had excess provision against their NPLs in December 2011.

\subsubsection{Writing-of Bad Debts}

To wipe out unnecessarily and artificially inflated size of balance sheet, uniform guidelines of write-off have been introduced in 2003. According to the policy, banks may, at any time, classify write-off loans as bad/loss. Those loans, which have been classified as bad/loss for the last 5 years and above and loans for which 100 percent provisions have been kept, should be written-off immediately. The total amounts of written-off bad debts from June 2004 to June 2012 in different categories of bank are presented in Table 3.7.1

Table 8. Writing-of bad debts in different bank categories (billion Taka)

\begin{tabular}{|l|l|l|l|l|l|l|l|l|l|l|}
\hline $\begin{array}{l}\text { Banks } \\
\text { Types }\end{array}$ & $\begin{array}{l}30 \text { June } \\
2004\end{array}$ & $\begin{array}{l}30 \text { June } \\
2005\end{array}$ & $\begin{array}{l}30 \text { June } \\
2006\end{array}$ & $\begin{array}{l}30 \text { June } \\
2007\end{array}$ & $\begin{array}{l}30 \text { June } \\
2008\end{array}$ & $\begin{array}{l}30 \text { June } \\
2009\end{array}$ & $\begin{array}{l}30 \text { June } \\
2010\end{array}$ & $\begin{array}{l}30 \\
2011\end{array}$ & $\begin{array}{l}30 \\
2012\end{array}$ \\
\hline SCB's & 26.3 & 29.7 & 35.7 & 42.8 & 48.4 & 64.5 & 70.5 & 82.4 & 92.3 \\
\hline DFI's & 17.4 & 27.6 & 28.6 & 30.4 & 31.0 & 31.8 & 31.8 & 32.0 & 32.3 \\
\hline PCB's & 21.2 & 32.9 & 40.7 & 45.5 & 49.4 & 54.7 & 69.6 & 77.1 & 85.5 \\
\hline FCB's & 0.9 & 1.1 & 1.5 & 1.6 & 1.7 & 2.0 & 2.1 & 2.4 & 2.9 \\
\hline Total & 65.8 & 91.3 & 106.5 & 120.3 & 130.5 & 153.0 & 174.0 & 193.9 & 213.0 \\
\hline
\end{tabular}

Source: Bangladesh Bank Annual Reports (2004-2011) 


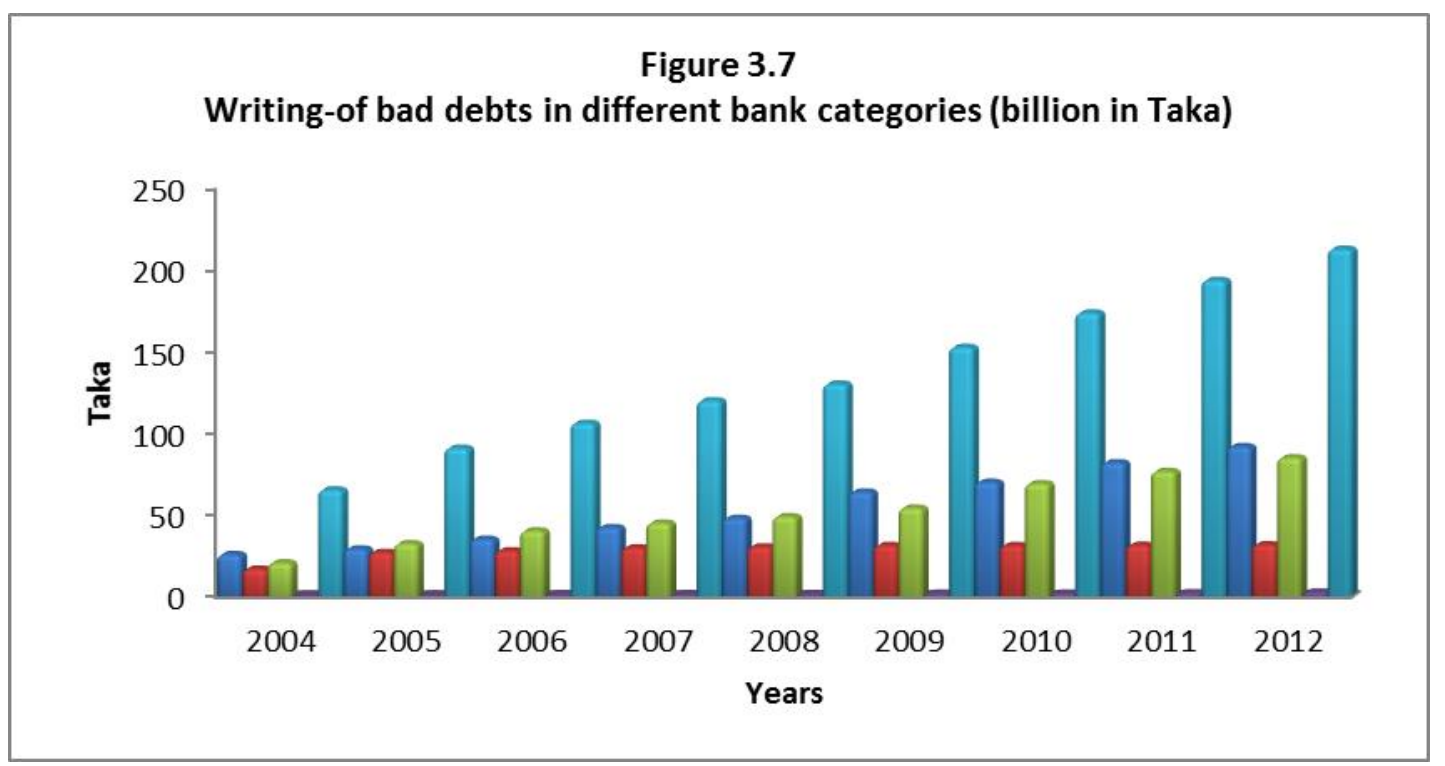

Source: Bangladesh Bank Annual Reports (2004-2011)

\subsubsection{Management Soundness}

Sound management is the most important and inevitable pre-requisite for the strength and concrete growth of any financial institution. Since indicators of management quality are primarily specific to individual institution, these cannot be easily aggregated across the sector. In addition, it is difficult to draw any conclusion regarding management soundness based on quantitative indicators, as characteristics of a good management are rather qualitative in nature. Nevertheless, the total expenditure to total income, operating expenses to total expenses, earnings and operating expenses per employee, and interest rate spread are generally used to portray management soundness. Technical competence \& leadership of mid and senior level management, compliance with banking laws and regulations, adequacy, compliance of sound internal policies, ability to plan and respond to changing circumstances etc. are also taken into consideration to illustrate the quality of management.

\subsubsection{Expenditure-Income Ratio}

Table 9. Expenditure-income ratio by type of banks (percent)

\begin{tabular}{|l|l|l|l|l|l|l|l|l|}
\hline Banks Types & 2004 & 2005 & 2006 & 2007 & 2008 & 2009 & 2010 & 2011 \\
\hline SCB's & 102.3 & 101.9 & 100.0 & 100.0 & 89.6 & 75.6 & 80.7 & 62.7 \\
\hline DFI's & 104.0 & 103.9 & 103.5 & 107.7 & 103.7 & 112.1 & 87.8 & 88.6 \\
\hline PCB's & 87.1 & 89.3 & 90.2 & 88.8 & 88.4 & 72.6 & 67.6 & 71.7 \\
\hline FCB's & 76.3 & 70.8 & 71.1 & 72.9 & 75.8 & 59.0 & 64.7 & 47.3 \\
\hline Total & 90.9 & 92.2 & 91.4 & 90.4 & 87.9 & 72.6 & 70.8 & 68.6 \\
\hline
\end{tabular}

Source: Bangladesh Bank Annual Reports (2004-2011) 


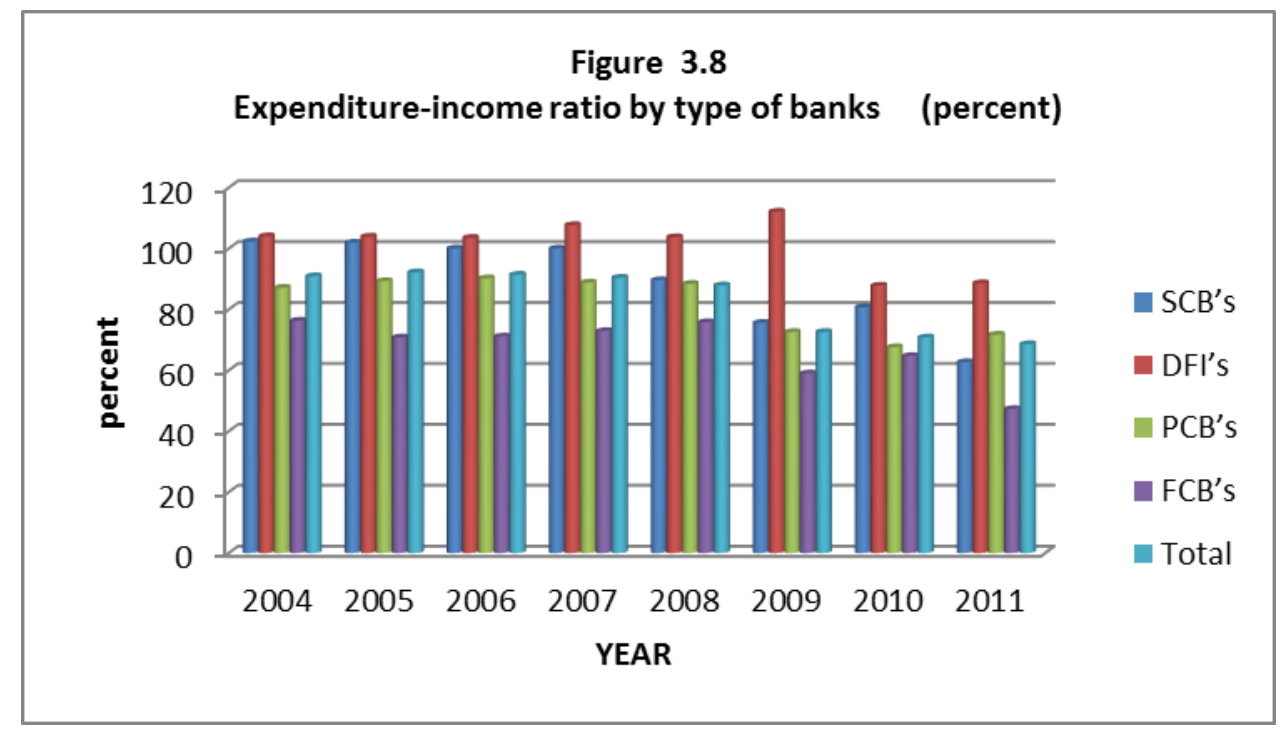

Source: Bangladesh Bank Annual Reports (2004-2011)

As evident from Table 9 and Figure 3.8, in 2011, the expenditure-income (EI) ratio of the DFIs was the highest among the shown bank clusters due to poor non-interest income and higher operating expenses. The EI ratio of the PCBs was 71.7, the second highest, which could mainly be attributable to high administrative and operating expenses. The EI ratio of the SCBs fell from 80.7 in 2010 to 62.7 in 2011 mainly due to significant increase (Taka 60.5 billion to Taka 91.7 billion) in interest income.

\subsubsection{Earning Performance}

Strong earnings and profitability profile of a bank reflect its ability to support present and future sound operation, absorb future contingent shocks and strengthen resilience capacity. More specifically, this determines the capacity to absorb losses by building an adequate capital base, finance its expansion and pay adequate dividends to its shareholders. Although there are various indicators of earning and profitability, the most representative and widely used indicator is Return on Assets (ROA), which is supplemented by Return on Equity (ROE) and Net Interest Margin (NIM).

\subsubsection{Return on Assets (ROA)}

Return on Assets (ROA) indicates the productivity of assets i.e. how much income is earned from per unit of assets. According to Basel-II accord, ROA should be more than $1 \%$.

Table 10. Return on assets (ROA) (Percent)

\begin{tabular}{|l|l|l|l|l|l|l|l|l|}
\hline Banks Types & 2004 & 2005 & 2006 & 2007 & 2008 & 2009 & 2010 & 2011 \\
\hline SCB's & -0.1 & -0.1 & 0.0 & 0.0 & 0.7 & 1.0 & 1.1 & 1.3 \\
\hline DFI's & -0.2 & -0.1 & -0.2 & -0.3 & -0.6 & 0.4 & 0.2 & .1 \\
\hline PCB's & 1.2 & 1.1 & 1.1 & 1.3 & 1.4 & 1.6 & 2.1 & 1.6 \\
\hline FCB's & 3.2 & 3.1 & 2.2 & 3.1 & 2.9 & 3.2 & 2.9 & 3.2 \\
\hline Total & $\mathbf{0 . 7}$ & $\mathbf{0 . 6}$ & $\mathbf{0 . 8}$ & $\mathbf{0 . 9}$ & $\mathbf{1 . 2}$ & $\mathbf{1 . 4}$ & $\mathbf{1 . 8}$ & $\mathbf{1 . 5}$ \\
\hline
\end{tabular}

Source: Bangladesh Bank Annual Reports (2004-2011) 


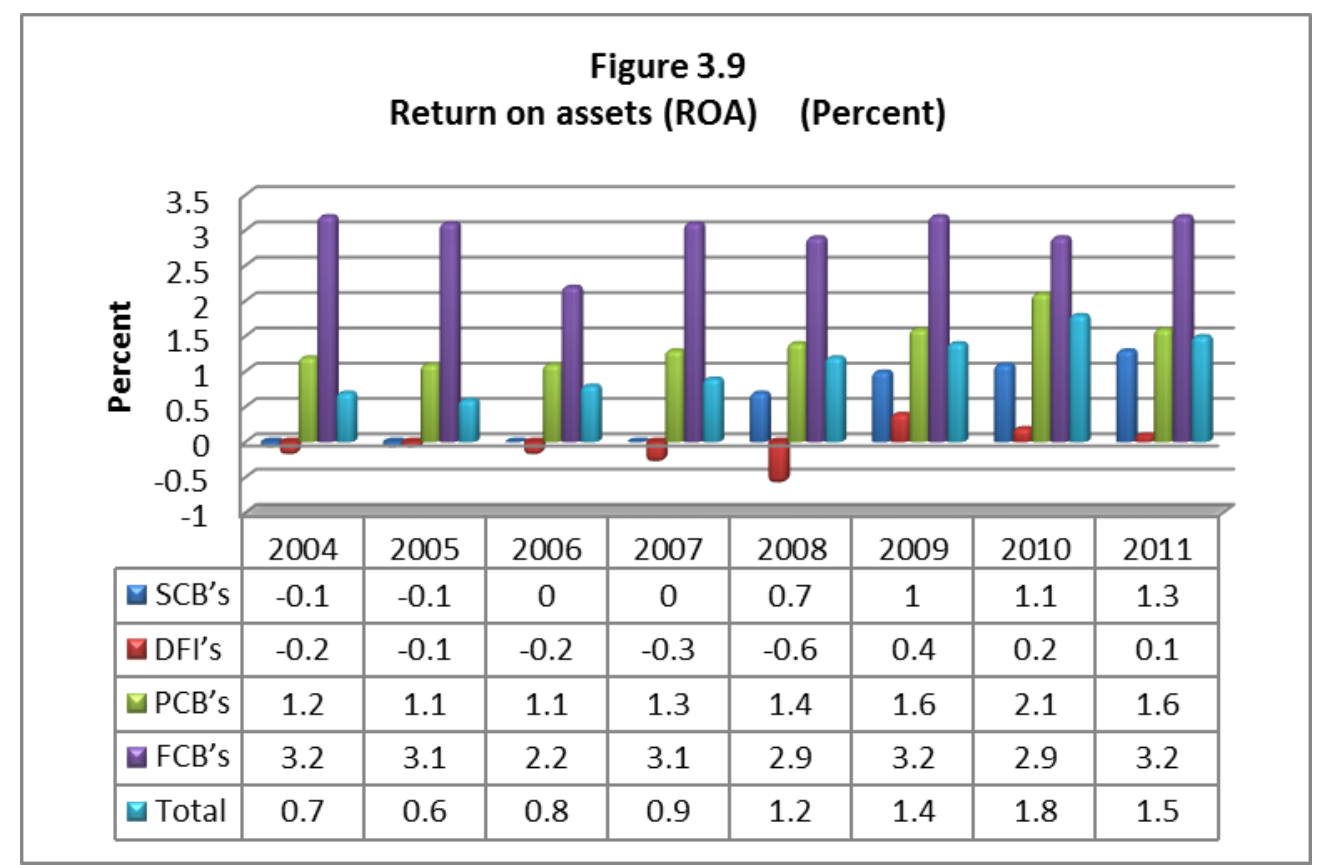

Source: Bangladesh Bank Annual Reports (2004-2011)

The Table 10 and Figure 3.9 show that SCBs achieved nearly zero percent of ROA over the whole period. The scenario is much worst in case of DFIs where most of the time ROA was negative. The reason behind this worse scenario of SCBs and DFIs is huge provision shortfall and insignificant profit during the period. PCBs ROA was below the standard level but gradually it was improved and reached at 2\% in June, 2010 but again down to $1.6 \%$ in 2011 . FCBs ROA position is well strong over the whole period.

\subsubsection{Return on Equity (ROE)}

Return on Equity (ROE) is another important measure of earning and profitability determination which indicates net income after tax to total equity. The amount of profit generation for the equity shareholders is found from the ratio. Higher value of ROE is an indication of high productivity of equity.

Table 11. Return on equity (ROE) (Percent)

\begin{tabular}{|l|l|l|l|l|l|l|l|l|}
\hline Banks Types & 2004 & 2005 & 2006 & 2007 & 2008 & 2009 & 2010 & 2011 \\
\hline SCB's & -5.3 & -6.9 & 0.0 & 0.0 & 22.5 & 26.2 & 18.4 & 19.7 \\
\hline DFI's & -2.1 & -2.0 & -2.0 & -3.4 & -6.9 & -171.7 & -3.2 & -0.9 \\
\hline PCB's & 19.5 & 18.1 & 15.2 & 16.7 & 16.4 & 21.0 & 20.9 & 15.7 \\
\hline FCB's & 22.5 & 18.4 & 21.5 & 20.4 & 17.8 & 22.4 & 17.0 & 16.6 \\
\hline Total & 13.0 & 12.4 & 14.1 & 13.8 & 15.6 & 21.7 & 21.0 & 17.0 \\
\hline
\end{tabular}

Source: Bangladesh Bank Annual Reports (2004-2011) 


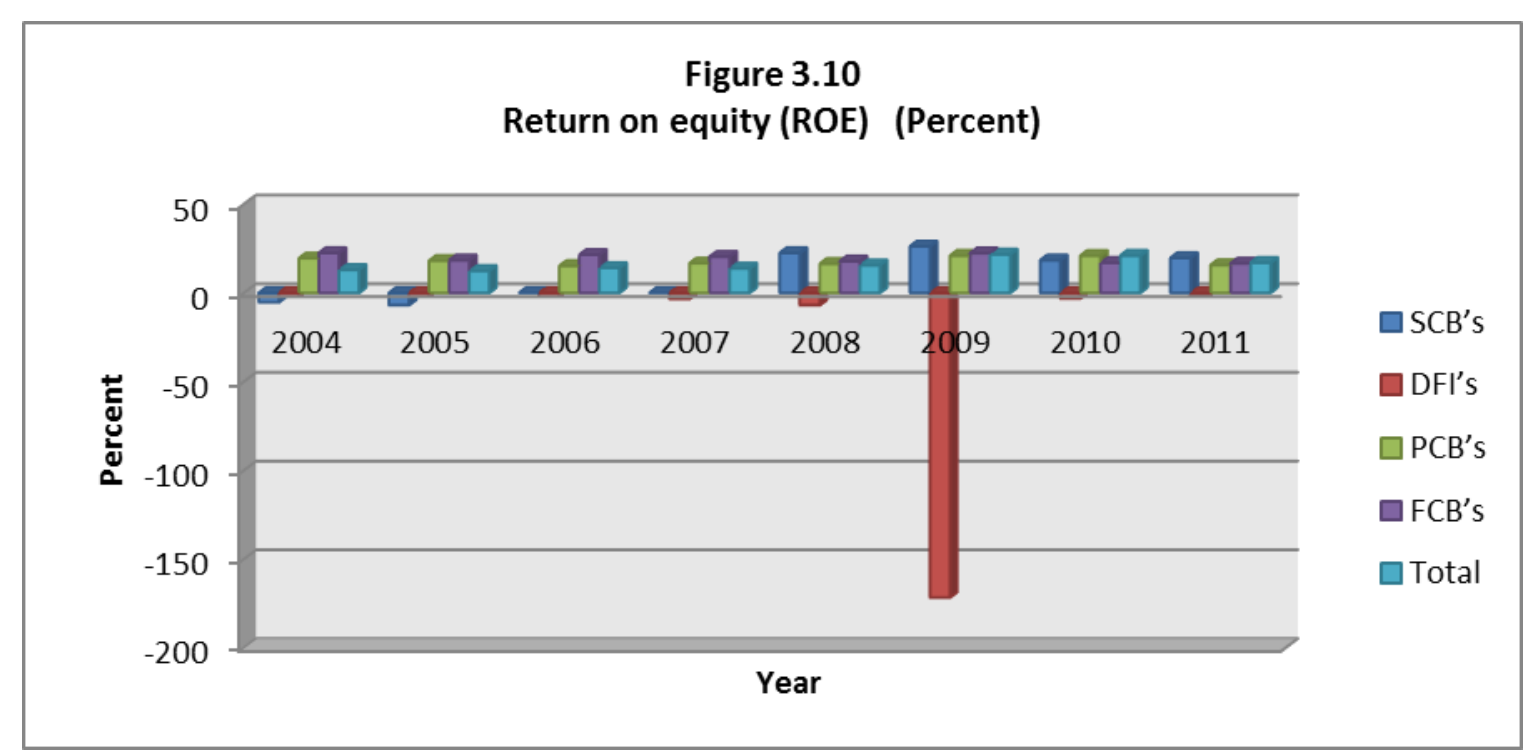

Source: Bangladesh Bank Annual Reports (2004-2011)

The Table 11 and Figure 3.10 show that the SCBs' ROE was 26.2 percent in 2009, but dropped down to 18.4 percent in 2010 as owners' equity had increased comparatively at a higher rate than after tax profit. However, it increased to 19.7 percent in 2011. In case of the DFIs, the ROE was still negative in 2011. The ROE of the PCBs was diverse but satisfactory (except the year 2011) during the last five years. The ROE of the FCBs has been showing gradual decline from 2009 due to increase in equity. The ROE of the FCBs in 2009 stood at 22.4 percent, which declined to 16.6 percent in 2011.

\subsubsection{Net Interest Income (NII)}

Another important tool to indicate the earning and profitability is Net Interest Income (NII). Net interest income is the spread between interest receipts from loans and advances and interest paid to the depositors. The high NII means the spread between interest receipts and paid is high.

Table 12. Net interest income by type of banks (billion Taka)

\begin{tabular}{|l|l|l|l|l|l|l|l|l|}
\hline Banks Types & 2004 & 2005 & 2006 & 2007 & 2008 & 2009 & 2010 & 2011 \\
\hline SCB's & -1.1 & 7.7 & 9.0 & 7.4 & 7.9 & 12.1 & 19.8 & 34.3 \\
\hline DFI's & 1.8 & 1.0 & 1.7 & 1.4 & 1.9 & 1.9 & 6.2 & 4.9 \\
\hline PCB's & 13.7 & 21.0 & 25.4 & 36.1 & 48.5 & 56.7 & 82.8 & 91.4 \\
\hline FCB's & 4.2 & 5.6 & 8.2 & 9.9 & 12.6 & 10.7 & 13.0 & 16.1 \\
\hline Total & 18.3 & 35.3 & 44.3 & 54.8 & 70.9 & 81.5 & 121.9 & 146.7 \\
\hline
\end{tabular}

Source: Bangladesh Bank Annual Reports (2004-2011) 


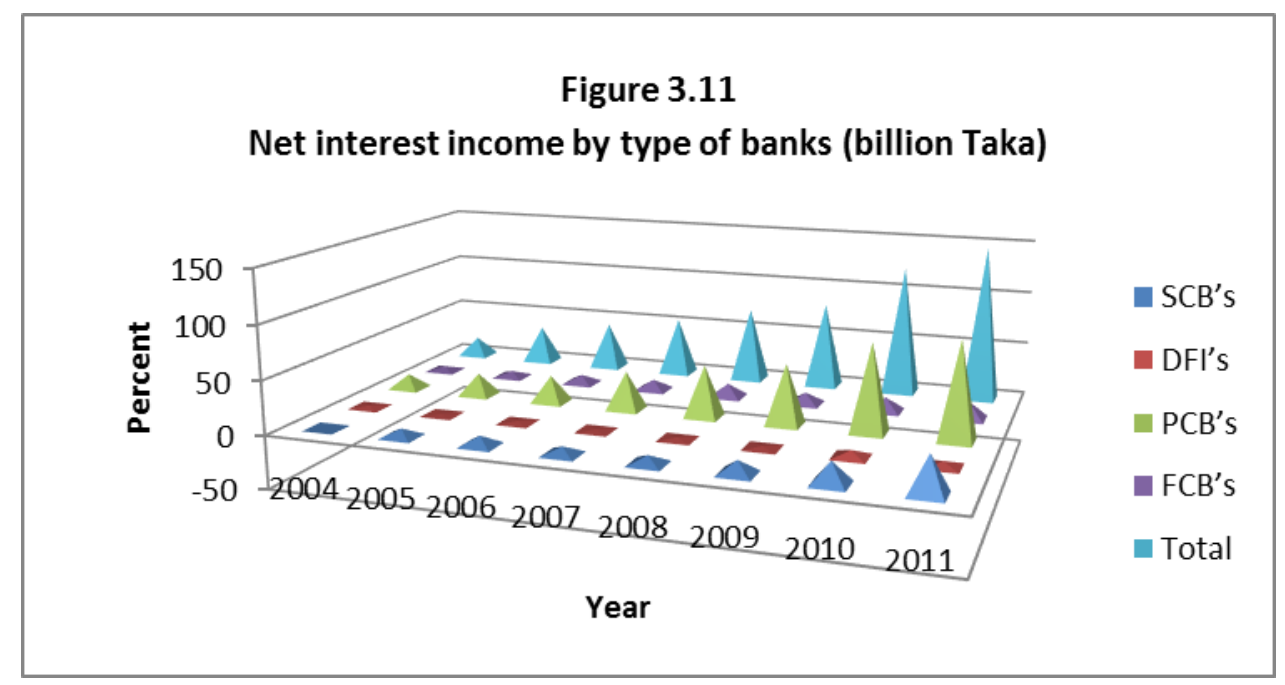

Source: Bangladesh Bank Annual Reports (2004-2011)

The aggregate net interest income (NII) of the industry has consistently increased from Taka 18.3 billion in 2004 to Taka 146.7 billion in 2011. However, the NII of the SCBs was a negative amount of Taka 1.1 billion in 2004 and had started to become positive (Taka 7.7 billion) from 2005. In 2011, the NII of the SCBs was Taka 34.3 billion. The DFIs had a positive trend in NII since 2002 and it was Taka 4.9 billion in 2011.

Since 2005, the SCBs have been able to increase NII by reducing their cost of fund. The NII of the PCBs has been incredibly high over the period from 2004 through 2011. The overall industry NII shows a consistently upward trend. The trend of NII indicates that the PCBs and the FCBs' interest spreads are higher than those of the SCBs and the DFIs.

\subsubsection{Liquidity}

Statutory liquidity reserve (SLR) varies according to the circular issued by the Bangladesh Bank but in an average SLR is $18.5 \%$ of total deposits including cash reserve requirement at least 5\% in Bangladesh Bank account. Three DFIs are exempted from the requirement of SLR and 7 Islami banks have to keep $10 \%$ SLR. Rest of all banks has to maintain the required SLR [Bangladesh Bank].

\subsubsection{Liquid Assets}

Table 13. Liquid assets (Percent)

\begin{tabular}{|l|l|l|l|l|l|l|l|l|}
\hline Banks Types & 2004 & 2005 & 2006 & 2007 & 2008 & 2009 & 2010 & 2011 \\
\hline SCB's & 22.8 & 20.0 & 20.1 & 24.9 & 32.9 & 25.1 & 27.2 & 34.7 \\
\hline DFI's & 11.2 & 11.2 & 11.9 & 14.2 & 13.7 & 9.6 & 21.3 & 12.3 \\
\hline PCB's & 23.1 & 21.0 & 21.4 & 22.2 & 20.7 & 18.2 & 21.5 & 23.9 \\
\hline FCB's & 37.8 & 41.5 & 34.4 & 29.2 & 31.3 & 31.8 & 32.1 & 30.5 \\
\hline Total & 23.4 & 21.7 & 21.5 & 23.2 & 24.8 & 20.6 & 23.0 & 26.5 \\
\hline
\end{tabular}

Source: Bangladesh Bank Annual Reports (2004-2011) 


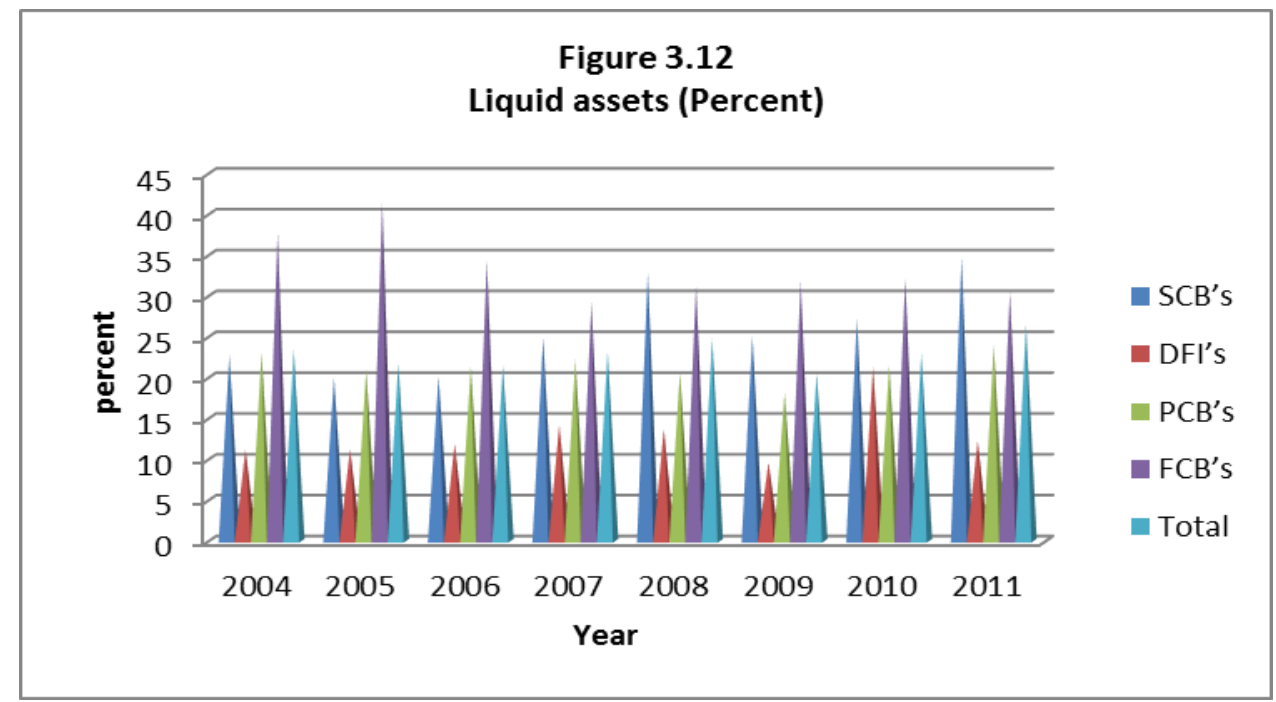

Source: Bangladesh Bank Annual Reports (2004-2011)

From the Table 13 \& Figure 3.12, we find that all the banks have liquid assets. In 2011, SCBs possessed highest liquid assets which are more than six times higher than that of PCBs in 2011. FCBs had highest liquid assets over the whole period except in 2008 \& 2011. PCBs \& DFIs liquid assets are lower than industry liquid assets over last eight years.

\subsubsection{Excess Liquidity}

Table 14. Excess liquidity (Percent)

\begin{tabular}{|l|l|l|l|l|l|l|l|l|}
\hline Banks Types & 2004 & 2005 & 2006 & 2007 & 2008 & 2009 & 2010 & 2011 \\
\hline SCB's & 6.8 & 2.0 & 2.1 & 6.9 & 14.9 & 17.6 & 8.2 & 15.7 \\
\hline DFI's & 4.7 & 6.2 & 3.8 & 5.6 & 4.9 & 7.1 & 2.3 & 2.5 \\
\hline PCB's & 8.8 & 5.1 & 5.6 & 6.4 & 4.7 & 5.3 & 4.6 & 7.0 \\
\hline FCB's & 21.9 & 23.6 & 16.4 & 11.2 & 13.3 & 21.8 & 13.2 & 11.8 \\
\hline Total & 8.7 & 5.3 & 5.1 & 6.9 & 8.4 & 9.0 & 6.0 & 9.3 \\
\hline
\end{tabular}

Source: Bangladesh Bank Annual Reports (2004-2011)

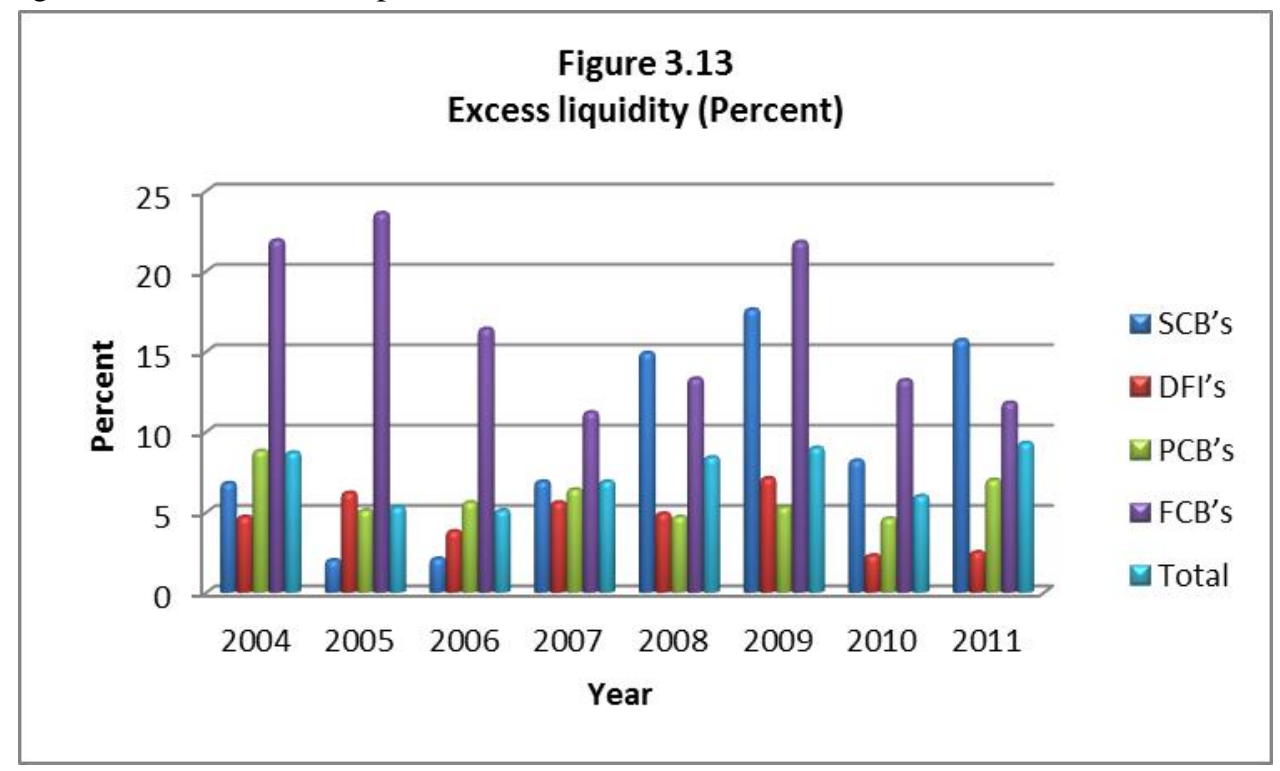

Source: Bangladesh Bank Annual Reports (2004-2011) 


\section{NI Macrothink}

Business and Economic Research ISSN 2162-4860 2014, Vol. 4, No. 1

From the Table 14 \& Figure 3.13, we find that all the banks had excess liquidity. In 2011, SCBs possessed highest excess liquidity which is more than six times higher than that of PCBs in 2011. FCBs had highest excess liquidity over the whole period except in 2008 \& 2011. PCBs \& DFIs excess liquidity is lower than industry excess liquidity over last five years. Excess liquidity indicates available loan able fund at low cost.

\subsubsection{CAMEL Rating of All Banks}

CAMEL rating is expressed on a scale of 1 to 5 in ascending order of supervisory concern, 1 representing the best rating, while 5 indicating the worst. Any bank rated 4 or 5 i.e. Marginal or Unsatisfactory under composite CAMEL rating is generally identified as a problem bank. Activities of these banks are closely monitored by the BB.

On the basis of five components of CAMEL banks are rated from 2004 to 2011.

Table 15. CAMEL rating of all Banks in Bangladesh

\begin{tabular}{|l|l|l|l|l|l|l|l|l|}
\hline Rating & 2004 & 2005 & 2006 & 2007 & 2008 & 2009 & 2010 & 2011 \\
\hline 1 or Strong & 12 & 13 & 3 & 6 & 2 & 3 & 5 & 2 \\
\hline 2 or Satisfactory & 15 & 16 & 31 & 29 & 28 & 32 & 32 & 33 \\
\hline 3 or Fair & 10 & 8 & 7 & 5 & 10 & 7 & 7 & 9 \\
\hline 4 or Marginal & 8 & 6 & 5 & 6 & 4 & 4 & 2 & 2 \\
\hline 5 or Unsatisfactory & 4 & 5 & 2 & 2 & 4 & 1 & 1 & 1 \\
\hline Total & 49 & 48 & 48 & 48 & 48 & 48 & 47 & 47 \\
\hline
\end{tabular}

Source: Bangladesh Bank Annual Reports (2004-2011)

As of end 2011, CAMEL rating of 2 banks was 1 or Strong; 33 banks were rated 2 or Satisfactory; 9 banks were rated 3 or Fair; 2 were rated 4 or Marginal and 1 bank got 5 or Unsatisfactory rating.

\section{Analysis \& Interpretation}

\subsection{Deposits}

Hypothesis Testing

The researcher wanted to find out that if there is any significant difference regarding the performance related to deposits among all the four banking groups during 2004 to 2011 or not. This was tested as under

\section{Null Hypothesis}

There is no significant difference in total deposits among all the banking groups during 2004 to 2011.

$\mathrm{H} 0=\mu 1=\mu 2=\mu 3=\mu 4$

$\mathrm{H} 1=\mu 1 \neq \mu 2 \neq \mu 3 \neq \mu 4$ 
Descriptive

\begin{tabular}{|c|c|c|c|c|c|c|c|c|}
\hline & $\mathrm{N}$ & Mean & $\begin{array}{c}\text { Std. } \\
\text { Deviation }\end{array}$ & Std. Error & \multicolumn{2}{|c|}{$\begin{array}{r}\text { 95\% Confidence Interval for } \\
\text { Mean }\end{array}$} & Minimum & Maximum \\
\hline & & & & & Lower Bound & Upper Bound & & \\
\hline SCB's & 8 & 797.0625 & 238.28992 & 84.24821 & 597.8471 & 996.2779 & 544.56 & 1235.65 \\
\hline DFI's & 8 & 134.6375 & 48.66882 & 17.20703 & 93.9493 & 175.3257 & 75.10 & 214.40 \\
\hline PCB's & 8 & 1465.2625 & 771.35661 & 272.71575 & 820.3922 & 2110.1328 & 588.00 & 2787.50 \\
\hline FCB's & 8 & 196.6075 & 60.24405 & 21.29949 & 146.2422 & 246.9728 & 108.44 & 284.80 \\
\hline Total & 32 & 648.3925 & 668.74615 & 118.21873 & 407.2838 & 889.5012 & 75.10 & 2787.50 \\
\hline
\end{tabular}

ANOVA Table

\begin{tabular}{|c|c|c|c|c|c|c|}
\hline & Sum of Squares & df & Mean Square & F & Sig. & 5\% F Limit (From table F) \\
\hline Between Groups & 9259466.016 & 3 & 3086488.672 & 18.769 & .000 & F $(3,28) 2.93$ \\
\hline Within Groups & 4604397.788 & 28 & 164442.778 & & & \\
\hline Total & 13863863.805 & 31 & & & & \\
\hline
\end{tabular}

The above ANOVA table indicates that the calculated value of $\mathrm{F}$ is 18.77 , which is more than the table value of 2.93 at $5 \%$ level of significance. Hence, the null hypothesis is rejected. It means that there is a significant difference in total deposits among all the four banking groups.

\subsection{Capital Adequacy Ratio (CAR)}

Hypothesis Testing

The researcher wanted to find out that if there is any significant difference regarding the performance related to capital Adequacy Ratio among all the four banking groups during 2004 to 2011 or not. This was tested as under.

\section{Null Hypothesis}

There is no significant different in capital adequacy ratio among all the four banking groups during 2004 to 2011.

$\mathrm{H} 0=\mu 1=\mu 2=\mu 3=\mu 4$

$\mathrm{H} 1=\mu 1 \neq \mu 2 \neq \mu 3 \neq \mu 4$

\section{Descriptives}

\begin{tabular}{|c|c|c|c|c|c|c|c|c|}
\hline & $\mathrm{N}$ & \multirow{2}{*}{ Mean } & $\begin{array}{c}\text { Std. } \\
\text { Deviation }\end{array}$ & $\begin{array}{c}\text { Std. } \\
\text { Error }\end{array}$ & \multicolumn{2}{|c|}{$\begin{array}{c}\text { 95\% Confidence Interval for } \\
\text { Mean }\end{array}$} & Minimum & Maximum \\
\hline & & & & & Lower Bound & Upper Bound & & \\
\hline SCB's & 8 & 6.1575 & 4.19069 & 1.48163 & 2.6540 & 9.6610 & -.40 & 11.70 \\
\hline DFI's & 8 & -3.4125 & 5.64205 & 1.99476 & -8.1294 & 1.3044 & -7.50 & 9.10 \\
\hline PCB's & 8 & 10.6125 & 0.99490 & .35175 & 9.7807 & 11.4443 & 9.10 & 12.10 \\
\hline FCB's & 8 & 23.0375 & 3.71058 & 1.31189 & 19.9354 & 26.1396 & 15.60 & 28.10 \\
\hline Total & 32 & 9.0988 & 10.38481 & 1.83579 & 5.3546 & 12.8429 & -7.50 & 28.10 \\
\hline
\end{tabular}


ANOVA Table

\begin{tabular}{|c|c|c|c|c|c|c|}
\hline Source of Variable & SS & DF & MS & F Ratio & Sig. & 5\% F Limit (From table F) \\
\hline Between Sample & 2894 & 3 & 964.7 & 60.15 & .000 & F $(3,28) 2.93$ \\
\hline Within Sample & 449.1 & 28 & 16.04 & & & \\
\hline Total & 3343 & 31 & & & & \\
\hline
\end{tabular}

The above ANOVA table indicates that the calculated value of $\mathrm{F}$ is 60.15 , which is more than the table value of 2.93 at $5 \%$ level of significance. Hence, the null hypothesis is rejected. It means that there is a significant difference in capital adequacy ratio between all the four banking groups.

\subsection{Assets Quality}

\subsubsection{NPLs to Total Loans Ratios}

Hypothesis Testing

The researcher wanted to find out that if there is any significant difference regarding the performance related to Non Performing Loans to total loans ratios among all the four banking groups during 2004 to 2011 or not. This was tested as under.

\section{Null Hypothesis:}

There is no significant different in Non Performing Loans to total loans ratios among all the four banking groups during 2004 to 2011.

$$
\begin{aligned}
& \mathrm{H} 0=\mu 1=\mu 2=\mu 3=\mu 4 \\
& \mathrm{H} 1=\mu 1 \neq \mu 2 \neq \mu 3 \neq \mu 4
\end{aligned}
$$

\section{Descriptives}

\begin{tabular}{|c|c|c|c|c|c|c|c|c|}
\hline & \multirow{2}{*}{$\mathrm{N}$} & \multirow{2}{*}{ Mean } & $\begin{array}{c}\text { Std. } \\
\text { Deviation }\end{array}$ & $\begin{array}{c}\text { Std. } \\
\text { Error }\end{array}$ & \multicolumn{2}{|c|}{$\begin{array}{c}\text { 95\% Confidence Interval for } \\
\text { Mean }\end{array}$} & Minimum & Maximum \\
\hline & & & & & Lower Bound & Upper Bound & & \\
\hline SCB's & 8 & 21.6625 & 5.85124 & 2.06872 & 16.7707 & 26.5543 & 11.30 & 29.90 \\
\hline DFI's & 8 & 30.0375 & 6.61080 & 2.33727 & 24.5107 & 35.5643 & 24.20 & 42.90 \\
\hline PCB's & 8 & 4.8750 & 1.77100 & .62614 & 3.3944 & 6.3556 & 2.90 & 8.50 \\
\hline FCB's & 8 & 1.8875 & .78819 & .27867 & 1.2286 & 2.5464 & .80 & 3.00 \\
\hline Total & 32 & 14.6156 & 12.60684 & 2.22859 & 10.0704 & 19.1609 & .80 & 42.90 \\
\hline
\end{tabular}

ANOVA Table

\begin{tabular}{|c|c|c|c|c|c|c|}
\hline & Sum of Squares & df & Mean Square & F & Sig. & 5\% F Limit (From table F) \\
\hline Between Groups & 4355.021 & 3 & 1451.674 & $\begin{array}{c}71.07 \\
6\end{array}$ & 0.000 & F (3,28) 2.93 \\
\hline Within Groups & 571.881 & 28 & 20.424 & & & \\
\hline Total & 4926.902 & 31 & & & & \\
\hline
\end{tabular}




\section{Macrothink}

Business and Economic Research ISSN 2162-4860 2014, Vol. 4, No. 1

The above ANOVA table indicates that the calculated value of $\mathrm{F}$ is 71.08 , which is more than the table value of 2.93 at $5 \%$ level of significance. Hence, the null hypothesis is rejected. It means that there is a significant difference in Non Performing Loans to total loans ratios among all the four banking groups.

\subsubsection{Ratio of net NPL to Total Loans}

Hypothesis Testing

The researcher wanted to find out that if there is any significant difference regarding the performance related to Ratio of net Non Performing Loans to total loans among all the four banking groups during 2004 to 2011 or not. This was tested as under.

\section{Null Hypothesis:}

There is no significant different in Ratio of net Non Performing Loans to total loans ratios among all the four banking groups during 2004 to 2011.

$$
\begin{aligned}
& \mathrm{H} 0=\mu 1=\mu 2=\mu 3=\mu 4 \\
& \mathrm{H} 1=\mu 1 \neq \mu 2 \neq \mu 3 \neq \mu 4
\end{aligned}
$$

\section{Descriptives}

\begin{tabular}{|c|c|c|c|c|c|c|c|c|}
\hline & $\mathrm{N}$ & Mean & $\begin{array}{c}\text { Std. } \\
\text { Deviation }\end{array}$ & $\begin{array}{c}\text { Std. } \\
\text { Error }\end{array}$ & \multicolumn{2}{|c|}{$\begin{array}{c}\text { 95\% Confidence Interval for } \\
\text { Mean }\end{array}$} & Minimum & Maximum \\
\hline & & & & & Lower Bound & Upper Bound & & \\
\hline SCB's & 8 & 8.4450 & 6.88955 & 2.43582 & 2.6852 & 14.2048 & -.34 & 17.60 \\
\hline DFI's & 8 & 19.5500 & 3.06128 & 1.08233 & 16.9907 & 22.1093 & 16.00 & 23.60 \\
\hline PCB's & 8 & 1.2000 & 1.16986 & .41361 & .2220 & 2.1780 & -.20 & 3.40 \\
\hline FCB's & 8 & -2.0000 & .35456 & .12536 & -2.2964 & -1.7036 & -2.60 & -1.50 \\
\hline Total & 32 & 6.7988 & 9.15964 & 1.61921 & 3.4963 & 10.1012 & -2.60 & 23.60 \\
\hline
\end{tabular}

ANOVA Table

\begin{tabular}{|c|c|c|c|c|c|c|}
\hline & Sum of Squares & df & Mean Square & F & Sig. & 5\% F Limit (From table F) \\
\hline Between Groups & 2192.548 & 3 & 730.849 & 50.117 & .000 & F (3,28) 2.93 \\
\hline Within Groups & 408.321 & 28 & 14.583 & & & \\
\hline Total & 2600.870 & 31 & & & & \\
\hline
\end{tabular}

The above ANOVA table indicates that the calculated value of $\mathrm{F}$ is 50.12 , which is more than the table value of 2.93 at $5 \%$ level of significance. Hence, the null hypothesis is rejected. It means that there is a significant difference in Ratio of net Non Performing Loans to total loans among all the four banking groups. The performance of all the banking groups regarding this ratio is different.

\subsection{Writing-Of Bad Debts}

Hypothesis Testing 


\section{Macrothink}

Business and Economic Research

ISSN 2162-4860

2014, Vol. 4, No. 1

The researcher wanted to find out that if there is any significant difference regarding Bad debts among all the four banking groups during 2004 to 2011 or not. This was tested as under.

Null Hypothesis

There is no significant different regarding Bad debts among all the four banking groups during 2004 to 2011.

$$
\begin{aligned}
& \mathrm{H} 0=\mu 1=\mu 2=\mu 3=\mu 4 \\
& \mathrm{H} 1=\mu 1 \neq \mu 2 \neq \mu 3 \neq \mu 4
\end{aligned}
$$

\begin{tabular}{|c|c|c|c|c|c|c|c|c|}
\hline & \multirow[t]{2}{*}{$\mathrm{N}$} & \multirow[t]{2}{*}{ Mean } & \multirow[t]{2}{*}{$\begin{array}{c}\text { Std. } \\
\text { Deviation }\end{array}$} & \multirow[t]{2}{*}{$\begin{array}{l}\text { Std. } \\
\text { Error }\end{array}$} & \multicolumn{2}{|c|}{$\begin{array}{c}\text { 95\% Confidence Interval for } \\
\text { Mean }\end{array}$} & \multirow[t]{2}{*}{ Minimum } & \multirow[t]{2}{*}{ Maximum } \\
\hline & & & & & Lower Bound & Upper Bound & & \\
\hline SCB's & 9 & 54.7333 & 23.71861 & 7.90620 & 36.5016 & 72.9651 & 26.30 & 92.30 \\
\hline DFI's & 9 & 29.2111 & 4.71446 & 1.57149 & 25.5873 & 32.8350 & 17.40 & 32.30 \\
\hline PCB's & 9 & 52.9556 & 21.06906 & 7.02302 & 36.7604 & 69.1507 & 21.20 & 85.50 \\
\hline FCB's & 9 & 1.8000 & .62650 & .20883 & 1.3184 & 2.2816 & .90 & 2.90 \\
\hline Total & 36 & 34.6750 & 26.64957 & 4.44160 & 25.6581 & 43.6919 & .90 & 92.30 \\
\hline
\end{tabular}

\section{Descriptives}

ANOVA Table

\begin{tabular}{|c|c|c|c|c|c|c|}
\hline & Sum of Squares & df & Mean Square & F & Sig. & 5\% F Limit (From table F) \\
\hline Between Groups & 16624.216 & 3 & 5541.405 & 21.539 & .000 & F (3,28) 2.85 \\
\hline Within Groups & 8232.771 & 32 & 257.274 & & & \\
\hline Total & 24856.988 & 35 & & & & \\
\hline
\end{tabular}

The above ANOVA table indicates that the calculated value of $\mathrm{F}$ is 21.54 , which is more than the table value of 2.93 at $5 \%$ level of significance. Hence, the null hypothesis is rejected again. It means that there is a significant difference in Bad debts among all the four banking groups. The performance of all the banking groups regarding this ratio is different.

\subsection{Management Soundness}

\subsubsection{Expenditure-income Ratio}

Hypothesis Testing

The researcher wanted to find out that if there is any significant difference regarding Expenditure-income among all the four banking groups during 2004 to 2011 or not. This was tested as under.

Null Hypothesis:

There is no significant different regarding Expenditure-income among all the four banking groups during 2004 to 2011 .

$\mathrm{H} 0=\mu 1=\mu 2=\mu 3=\mu 4$ 
$\mathrm{H} 1=\mu 1 \neq \mu 2 \neq \mu 3 \neq \mu 4$

\section{Descriptives}

\begin{tabular}{|c|c|c|c|c|c|c|c|c|}
\hline & \multirow[t]{2}{*}{$\mathrm{N}$} & \multirow[t]{2}{*}{ Mean } & \multirow[t]{2}{*}{$\begin{array}{l}\text { Std. } \\
\text { Deviation }\end{array}$} & \multirow[t]{2}{*}{$\begin{array}{l}\text { Std. } \\
\text { Error }\end{array}$} & \multicolumn{2}{|c|}{$\begin{array}{l}95 \% \text { Confidence Interval for } \\
\text { Mean }\end{array}$} & \multirow[t]{2}{*}{ Minimum } & \multirow[t]{2}{*}{ Maximum } \\
\hline & & & & & Lower Bound & Upper Bound & & \\
\hline SCB's & 8 & 89.1000 & 14.76347 & 5.21967 & 76.7574 & 101.4426 & 62.70 & 102.30 \\
\hline DFI's & 8 & 101.4125 & 8.66593 & 3.06387 & 94.1676 & 108.6574 & 87.80 & 112.10 \\
\hline PCB's & 8 & 81.9625 & 9.52844 & 3.36881 & 73.9965 & 89.9285 & 67.60 & 90.20 \\
\hline FCB's & 8 & 67.2375 & 9.90612 & 3.50234 & 58.9558 & 75.5192 & 47.30 & 76.30 \\
\hline Total & 32 & 84.9281 & 16.32434 & 2.88576 & 79.0426 & 90.8137 & 47.30 & 112.10 \\
\hline
\end{tabular}

ANOVA Table

\begin{tabular}{|l|l|l|l|l|l|l|}
\hline & Sum of Squares & df & Mean Square & F & Sig. & 5\% F Limit (From table F) \\
\hline Between Groups & 4887.138 & 3 & 1629.046 & 13.520 & .000 & F (3,28) 2.93 \\
\hline Within Groups & 3373.866 & 28 & 120.495 & & & \\
\hline Total & 8261.005 & 31 & & & & \\
\hline
\end{tabular}

The above ANOVA table indicates that the calculated value of $\mathrm{F}$ is 13.52 , which is more than the table value of 2.93 at $5 \%$ level of significance. Hence, the null hypothesis is rejected again. It means that there is a significant difference in expenditure-income ratio among all the four banking groups. The performance of all the banking groups regarding this ratio is different.

\subsection{Earning Performance}

\subsubsection{Return on Assets}

Hypothesis Testing

The researcher wanted to find out that if there is any significant difference regarding Return On Assets in \% among all the four banking groups during 2004 to 2011 or not. This was tested as under.

Null Hypothesis:

There is no significant difference regarding Return on Assets in \% among all the four banking groups during 2004 to 2011.

$\mathrm{H} 0=\mu 1=\mu 2=\mu 3=\mu 4$

$\mathrm{H} 1=\mu 1 \neq \mu 2 \neq \mu 3 \neq \mu 4$

\section{Descriptives}

\begin{tabular}{|l|l|l|l|l|l|l|l|}
\hline \multirow{2}{*}{$\mathrm{N}$} & \multirow{2}{*}{ Mean } & $\begin{array}{c}\text { Std. } \\
\text { Deviation }\end{array}$ & \multirow{2}{*}{$\begin{array}{c}\text { Std. } \\
\text { Error }\end{array}$} & \multicolumn{2}{|c|}{$\begin{array}{c}\text { 95\% Confidence Interval for } \\
\text { Mean }\end{array}$} & Minimum & Maximum \\
\cline { 5 - 7 } & & & Lower Bound & Upper Bound & & \\
\hline
\end{tabular}




\section{Macrothink}

Business and Economic Research ISSN 2162-4860 2014, Vol. 4, No. 1

\begin{tabular}{|c|c|c|c|c|c|c|c|c|}
\hline SCB's & 8 & 0.4875 & 0.59866 & 0.21166 & -0.0130 & 0.9880 & -0.10 & 1.30 \\
\hline DFI's & 8 & -0.0875 & 0.31368 & 0.11090 & -0.3497 & 0.1747 & -0.60 & .40 \\
\hline PCB's & 8 & 1.4250 & 0.33700 & 0.11915 & 1.1433 & 1.7067 & 1.10 & 2.10 \\
\hline FCB's & 8 & 2.9750 & 0.33700 & 0.11915 & 2.6933 & 3.2567 & 2.20 & 3.20 \\
\hline Total & 32 & 1.2000 & 1.24071 & 0.21933 & 0.7527 & 1.6473 & -0.60 & 3.20 \\
\hline
\end{tabular}

ANOVA Table

\begin{tabular}{|c|c|c|c|c|c|c|}
\hline & Sum of Squares & df & Mean Square & F & Sig. & 5\% F Limit (From table F) \\
\hline Between Groups & 42.932 & 3 & 14.311 & 83.698 & .000 & F $(3,28) 2.93$ \\
\hline Within Groups & 4.788 & 28 & .171 & & & \\
\hline Total & 47.720 & 31 & & & & \\
\hline
\end{tabular}

The above ANOVA table indicates that the calculated value of $\mathrm{F}$ is 83.70 , which is more than the table value of 2.93 at $5 \%$ level of significance. Hence, the null hypothesis is rejected again. It means that there is a significant difference in Return on Assets in \% among all the four banking groups. The performance of all the banking groups regarding this ratio is different.

\subsubsection{Return on Equity}

Hypothesis Testing

The researcher wanted to find out that if there is any significant difference regarding Return On equity among all the four banking groups during 2004 to 2011 or not. This was tested as under.

Null Hypothesis:

There is no significant difference regarding Return on equity among all the four banking groups during 2004 to 2011.

$$
\begin{aligned}
& \mathrm{H} 0=\mu 1=\mu 2=\mu 3=\mu 4 \\
& \mathrm{H} 1=\mu 1 \neq \mu 2 \neq \mu 3 \neq \mu 4
\end{aligned}
$$

\section{Descriptives}

\begin{tabular}{|c|c|c|c|c|c|c|c|c|}
\hline & \multirow{2}{*}{} & $\mathrm{N}$ & Mean & $\begin{array}{c}\text { Std. } \\
\text { Deviation }\end{array}$ & \multicolumn{2}{|c|}{$\begin{array}{c}\text { Std. } \\
\text { Error }\end{array}$} & & \multicolumn{2}{|c|}{$\begin{array}{r}95 \% \text { Confidence Interval for } \\
\text { Mean }\end{array}$} & \multirow{2}{*}{ Minimum } & Maximum \\
\cline { 6 - 10 } & & & & & Lower Bound & Upper Bound & & \\
\hline SCB's & 8 & 9.3250 & 13.62453 & 4.81700 & -2.0654 & 20.7154 & -6.90 & 26.20 \\
\hline DFI's & 8 & -24.0250 & 59.69675 & 21.10599 & -73.9327 & 25.8827 & -171.70 & -.90 \\
\hline PCB's & 8 & 17.9375 & 2.29965 & 0.81305 & 16.0149 & 19.8601 & 15.20 & 21.00 \\
\hline FCB's & 8 & 19.5750 & 2.41823 & 0.85497 & 17.5533 & 21.5967 & 16.60 & 22.50 \\
\hline Total & 32 & 5.7031 & 34.18884 & 6.04379 & -6.6233 & 18.0295 & -171.70 & 26.20 \\
\hline
\end{tabular}

ANOVA Table

\begin{tabular}{|l|l|l|l|l|l|l|}
\hline & Sum of Squares & df & Mean Square & F & Sig. & 5\% F Limit (From table F) \\
\hline
\end{tabular}




\begin{tabular}{|c|c|c|c|c|c|c|}
\hline Between Groups & 9911.906 & 3 & 3303.969 & 3.514 & 0.028 & F $(3,28) 2.93$ \\
\hline Within Groups & 26323.264 & 28 & 940.117 & & & \\
\hline Total & 36235.170 & 31 & & & & \\
\hline
\end{tabular}

The above ANOVA table indicates that the calculated value of $\mathrm{F}$ is 3.514 , which is more than the table value of 2.93 at $5 \%$ level of significance. Hence, the null hypothesis is rejected again. It means that there is a significant difference in Return on equity among all the four banking groups. The performance of all the banking groups regarding this ratio is different.

\subsubsection{Net Interest Income}

Hypothesis Testing

The researcher wanted to find out that if there is any significant difference regarding net interest income ratio among all the four banking groups during 2004 to 2011 or not. This was tested as under.

Null Hypothesis:

There is no significant difference regarding net interest income ratio among all the four banking groups during 2004 to 2011.

$\mathrm{H} 0=\mu 1=\mu 2=\mu 3=\mu 4$

$\mathrm{H} 1=\mu 1 \neq \mu 2 \neq \mu 3 \neq \mu 4$

\section{Descriptives}

\begin{tabular}{|c|c|c|c|c|c|c|c|c|}
\hline & \multirow[t]{2}{*}{$\mathrm{N}$} & \multirow[t]{2}{*}{ Mean } & \multirow[t]{2}{*}{$\begin{array}{c}\text { Std. } \\
\text { Deviation }\end{array}$} & \multirow[t]{2}{*}{$\begin{array}{l}\text { Std. } \\
\text { Error }\end{array}$} & \multicolumn{2}{|c|}{$\begin{array}{c}\text { 95\% Confidence Interval for } \\
\text { Mean }\end{array}$} & \multirow[t]{2}{*}{ Minimum } & \multirow[t]{2}{*}{ Maximum } \\
\hline & & & & & Lower Bound & Upper Bound & & \\
\hline SCB's & 8 & 12.1375 & 10.65738 & 3.76795 & 3.2277 & 21.0473 & -1.10 & 34.30 \\
\hline DFI's & 8 & 2.6000 & 1.87769 & .66386 & 1.0302 & 4.1698 & 1.00 & 6.20 \\
\hline PCB's & 8 & 46.9500 & 28.58466 & 10.10620 & 23.0526 & 70.8474 & 13.70 & 91.40 \\
\hline FCB's & 8 & 10.0375 & 3.95869 & 1.39961 & 6.7279 & 13.3471 & 4.20 & 16.10 \\
\hline Total & 32 & 17.9313 & 22.74198 & 4.02025 & 9.7319 & 26.1306 & -1.10 & 91.40 \\
\hline
\end{tabular}

ANOVA Table

\begin{tabular}{|c|c|c|c|c|c|c|}
\hline & Sum of Squares & df & Mean Square & F & Sig. & 5\% F Limit (From table F) \\
\hline Between Groups & 9384.111 & 3 & 3128.037 & 13.173 & .000 & F $(3,28) 2.93$ \\
\hline Within Groups & 6649.018 & 28 & 237.465 & & & \\
\hline Total & 16033.129 & 31 & & & & \\
\hline
\end{tabular}

The above ANOVA table indicates that the calculated value of $F$ is 13.17 , which is more than the table value of 2.93 at $5 \%$ level of significance. Hence, the null hypothesis is rejected again. It means that there is a significant difference in net interest income ratio among all the four banking groups. The performance of all the banking groups regarding this ratio is different. 


\subsection{Liquidity}

\subsubsection{Liquid Assets}

Hypothesis Testing

The researcher wanted to find out that if there is any significant difference regarding liquid assets ratio among all the four banking groups during 2004 to 2011 or not. This was tested as under.

Null Hypothesis:

There is no significant difference regarding liquid assets ratio among all the four banking groups during 2004 to 2011.

$$
\begin{aligned}
& \mathrm{H} 0=\mu 1=\mu 2=\mu 3=\mu 4 \\
& \mathrm{H} 1=\mu 1 \neq \mu 2 \neq \mu 3 \neq \mu 4
\end{aligned}
$$

\section{Descriptives}

\begin{tabular}{|c|c|c|c|c|c|c|c|c|}
\hline & $\mathrm{N}$ & Mean & $\begin{array}{c}\text { Std. } \\
\text { Deviation }\end{array}$ & $\begin{array}{c}\text { Std. } \\
\text { Error }\end{array}$ & \multicolumn{2}{|c|}{$\begin{array}{c}\text { 95\% Confidence Interval for } \\
\text { Mean }\end{array}$} & Minimum & Maximum \\
\hline & & & & & Lower Bound & Upper Bound & & \\
\hline SCB's & 8 & 25.9625 & 5.44844 & 1.92632 & 21.4075 & 30.5175 & 20.00 & 34.70 \\
\hline DFI's & 8 & 13.1750 & 3.59196 & 1.26995 & 10.1721 & 16.1779 & 9.60 & 21.30 \\
\hline PCB's & 8 & 21.5000 & 1.71548 & 0.60651 & 20.0658 & 22.9342 & 18.20 & 23.90 \\
\hline FCB's & 8 & 33.5750 & 4.14789 & 1.46650 & 30.1073 & 37.0427 & 29.20 & 41.50 \\
\hline Total & 32 & 23.5531 & 8.39443 & 1.48394 & 20.5266 & 26.5796 & 9.60 & 41.50 \\
\hline
\end{tabular}

\section{ANOVA Table}

\begin{tabular}{|c|c|c|c|c|c|c|}
\hline & Sum of Squares & df & Mean Square & F & Sig. & 5\% F Limit (From table F) \\
\hline Between Groups & 1745.311 & 3 & 581.770 & 37.094 & .000 & F $(3,28) 2.93$ \\
\hline Within Groups & 439.149 & 28 & 15.684 & & & \\
\hline Total & 2184.460 & 31 & & & & \\
\hline
\end{tabular}

The above ANOVA table indicates that the calculated value of $\mathrm{F}$ is 9.554 , which is more than the table value of 2.93 at $5 \%$ level of significance. Hence, the null hypothesis is rejected again. It means that there is a significant difference in liquid assets ratio among all the four banking groups. The performance of all the banking groups regarding this ratio is different.

\subsubsection{Excess Liquidity}

Hypothesis Testing

The researcher wanted to find out that if there is any significant difference regarding Excess Liquidity ratio among all the four banking groups during 2004 to 2011 or not. This was tested as under. 
Null Hypothesis:

There is no significant difference regarding Excess Liquidity ratio among all the four banking groups during 2004 to 2011.

$\mathrm{H} 0=\mu 1=\mu 2=\mu 3=\mu 4$

$\mathrm{H} 1=\mu 1 \neq \mu 2 \neq \mu 3 \neq \mu 4$

\section{Descriptives}

\begin{tabular}{|c|c|c|c|c|c|c|c|c|}
\hline & \multirow[t]{2}{*}{$\mathrm{N}$} & \multirow[t]{2}{*}{ Mean } & \multirow[t]{2}{*}{$\begin{array}{l}\text { Std. } \\
\text { Deviation }\end{array}$} & \multirow[t]{2}{*}{$\begin{array}{l}\text { Std. } \\
\text { Error }\end{array}$} & \multicolumn{2}{|c|}{$\begin{array}{l}95 \% \text { Confidence Interval for } \\
\text { Mean }\end{array}$} & \multirow[t]{2}{*}{ Minimum } & \multirow[t]{2}{*}{ Maximum } \\
\hline & & & & & Lower Bound & Upper Bound & & \\
\hline SCB's & 8 & 9.2750 & 6.08928 & 2.15288 & 4.1842 & 14.3658 & 2.00 & 17.60 \\
\hline DFI's & 8 & 4.6375 & 1.70037 & .60117 & 3.2160 & 6.0590 & 2.30 & 7.10 \\
\hline PCB's & 8 & 5.9375 & 1.41819 & .50140 & 4.7519 & 7.1231 & 4.60 & 8.80 \\
\hline FCB's & 8 & 16.6500 & 5.05399 & 1.78686 & 12.4248 & 20.8752 & 11.20 & 23.60 \\
\hline Total & 32 & 9.1250 & 6.13882 & 1.08520 & 6.9117 & 11.3383 & 2.00 & 23.60 \\
\hline
\end{tabular}

ANOVA Table

\begin{tabular}{|c|c|c|c|c|c|c|}
\hline & Sum of Squares & df & Mean Square & F & Sig. & 5\% F Limit (From table F) \\
\hline Between Groups & 695.567 & 3 & 231.856 & 13.735 & .000 & F $(3,28) 2.93$ \\
\hline Within Groups & 472.673 & 28 & 16.881 & & & \\
\hline Total & 1168.240 & 31 & & & & \\
\hline
\end{tabular}

The above ANOVA table indicates that the calculated value of $F$ is 13.73 , which is more than the table value of 2.93 at $5 \%$ level of significance. Hence, the null hypothesis is rejected again. It means that there is a significant difference in Excess Liquidity ratio among all the four banking groups. The performance of all the banking groups regarding this ratio is different.

\subsection{Correlation Analysis}

\subsubsection{Correlation between CRAR and Interest Income}

CRAR will increase if capital increase at a rate higher than that of risk weighted assets increase. Here, it is seen that industry CRAR increased gradually and reach a satisfactory level of $11.4 \%$ in 2011 which is contributed by all type of banks except DFIs. Interest income also increased over the period. The correlation between CRAR and interest income shows a positive result which implies that increased capital base contributes to the interest income growth. The correlation between CRAR and interest income is highest in PCBs and lowest in DFIs over the period from 2004 to 2011. 


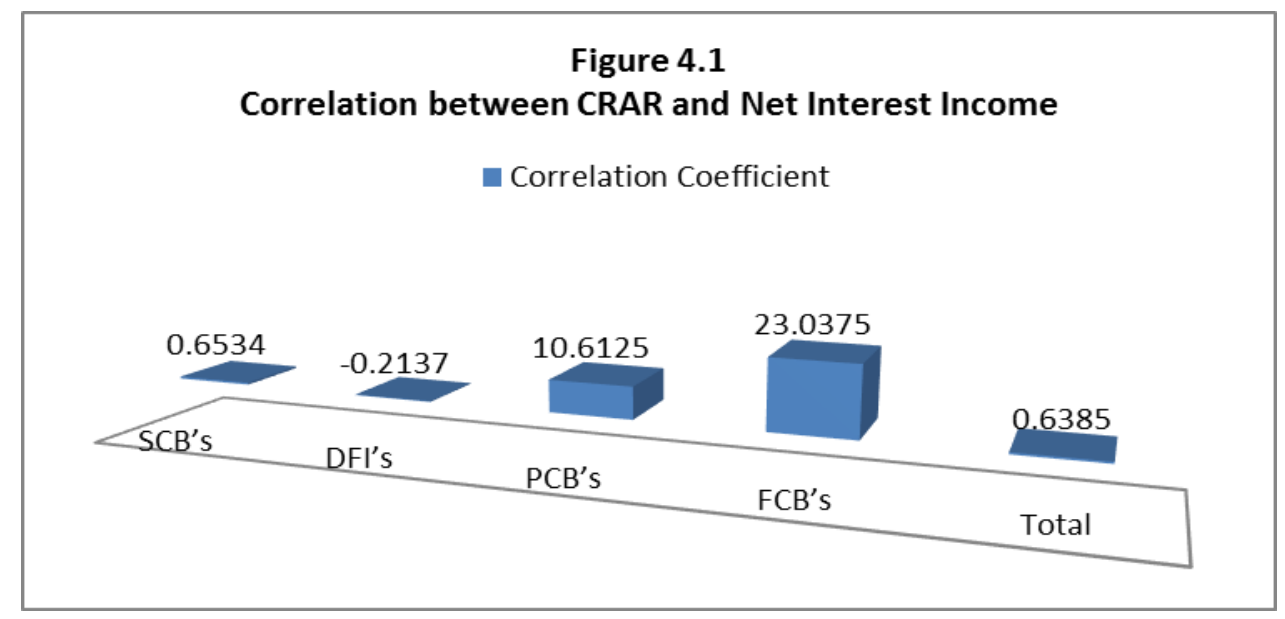

The industry correlation is 0.6385 which is significantly positive though DFI's correlation is negative. So, we can say that as increased CRAR positively correlated with interest income and it is possible for increasing the capital base which reduces the interest expenses to the depositors.

\subsubsection{Correlation between NPL to Loans Ratio and Interest income}

NPL adversely affects interest income. NPL reduces bank's profit in two ways-first interest suspense and second provision for NPL. Decreasing trend in NPL to loan ratio adversely correlated with the increasing trend of interest income (See Figure 4.2).

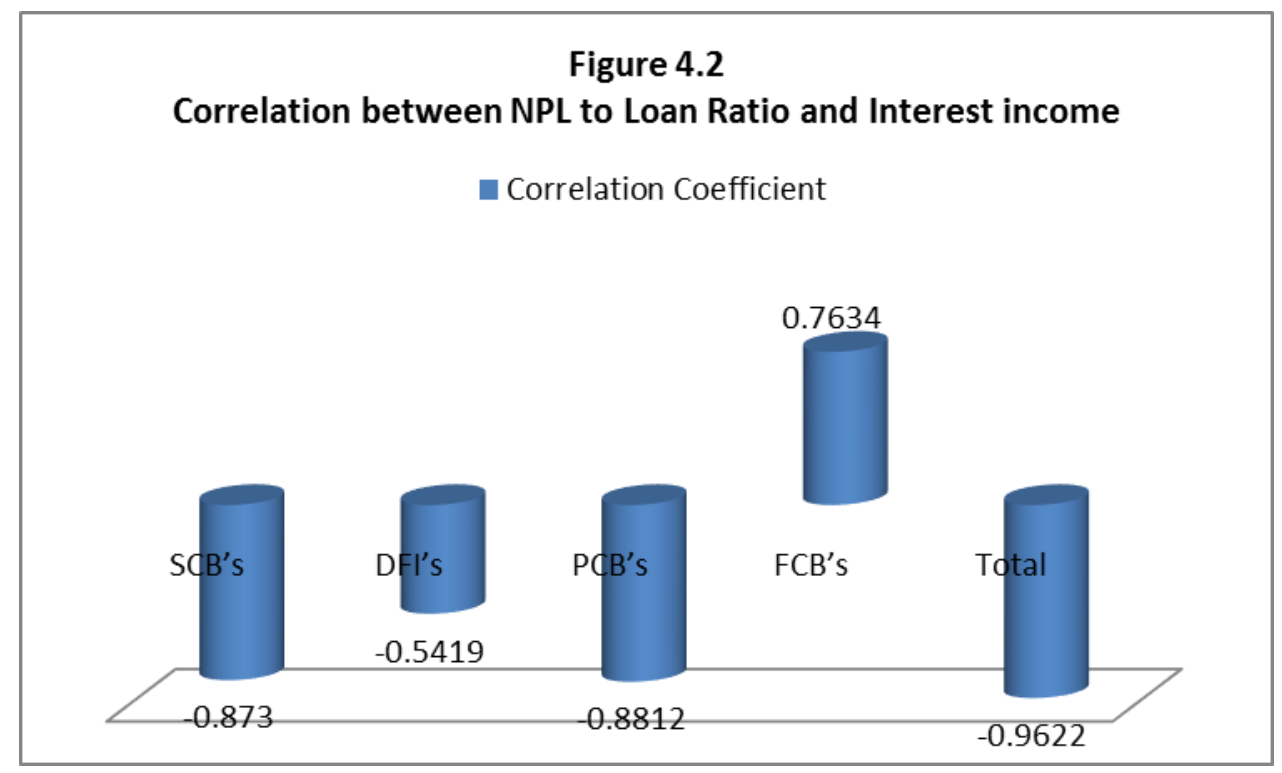

Figure 5.19 show that there exists negative correlation between NPL to loan and interest income. As NPL to loan ratio decreases, interest income increases and the correlation between this two criteria is -.9622 for the industry as a whole over the period. So, we can say that Banks should emphasize on reducing the NPL.

\subsection{Findings}

The performance of types of banks is not equal and there are some banks which are in need of 
monitoring closely to enhance sound banking. It is expected that the overall performance will be improved in near future provided that appropriate actions are taken in some lagged areas.

\subsubsection{Deposits}

The ANOVA table indicates that the calculated value of $\mathrm{F}$ is 18.77 , which is more than the table value of 2.93 at $5 \%$ level of significance. Hence, the null hypothesis is rejected. It means that there is a significant difference in total deposits among all the four banking groups.

\subsubsection{Capital Adequacy Ratio (Car)}

The ANOVA table indicates that the calculated value of $\mathrm{F}$ is 60.15 , which is more than the table value of 2.93 at $5 \%$ level of significance. Hence, the null hypothesis is rejected. It means that there is a significant difference in capital adequacy ratio between all the four banking groups.

\subsubsection{Npls to Total Loans Ratios}

The ANOVA table indicates that the calculated value of $\mathrm{F}$ is 71.08 , which is more than the table value of 2.93 at $5 \%$ level of significance. Hence, the null hypothesis is rejected. It means that there is a significant difference in Non Performing Loans to total loans ratios among all the four banking groups.

\subsubsection{Ratio of Net NPL to Total Loans}

The ANOVA table indicates that the calculated value of $\mathrm{F}$ is 50.12, which is more than the table value of 2.93 at $5 \%$ level of significance. Hence, the null hypothesis is rejected. It means that there is a significant difference in Ratio of net Non Performing Loans to total loans among all the four banking groups. The performance of all the banking groups regarding this ratio is different.

\subsubsection{Writing-of Bad Debts}

The ANOVA table indicates that the calculated value of $\mathrm{F}$ is 21.54 , which is more than the table value of 2.93 at $5 \%$ level of significance. Hence, the null hypothesis is rejected again. It means that there is a significant difference in Bad debts among all the four banking groups. The performance of all the banking groups regarding this ratio is different.

\subsubsection{Expenditure-income Ratio}

The ANOVA table indicates that the calculated value of $\mathrm{F}$ is 13.52 , which is more than the table value of 2.93 at $5 \%$ level of significance. Hence, the null hypothesis is rejected again. It means that there is a significant difference in expenditure-income ratio among all the four banking groups. The performance of all the banking groups regarding this ratio is different.

\subsubsection{Return on Assets}

The ANOVA table indicates that the calculated value of $\mathrm{F}$ is 83.70 , which is more than the table value of 2.93 at $5 \%$ level of significance. Hence, the null hypothesis is rejected again. It means that there is a significant difference in Return on Assets in \% among all the four banking groups. The performance of all the banking groups regarding this ratio is different. 


\subsubsection{Return on Equity}

The ANOVA table indicates that the calculated value of $\mathrm{F}$ is 3.514 , which is more than the table value of 2.93 at $5 \%$ level of significance. Hence, the null hypothesis is rejected again. It means that there is a significant difference in Return on equity among all the four banking groups. The performance of all the banking groups regarding this ratio is different.

\subsubsection{Net Interest Income}

The ANOVA table indicates that the calculated value of $\mathrm{F}$ is 13.17 , which is more than the table value of 2.93 at $5 \%$ level of significance. Hence, the null hypothesis is rejected again. It means that there is a significant difference in net interest income ratio among all the four banking groups. The performance of all the banking groups regarding this ratio is different.

\subsubsection{Liquid Assets}

The ANOVA table indicates that the calculated value of $\mathrm{F}$ is 9.554, which is more than the table value of 2.93 at $5 \%$ level of significance. Hence, the null hypothesis is rejected again. It means that there is a significant difference in liquid assets ratio among all the four banking groups. The performance of all the banking groups regarding this ratio is different.

\subsubsection{Excess Liquidity}

The ANOVA table indicates that the calculated value of $\mathrm{F}$ is 13.73 , which is more than the table value of 2.93 at $5 \%$ level of significance. Hence, the null hypothesis is rejected again. It means that there is a significant difference in Excess Liquidity ratio among all the four banking groups. The performance of all the banking groups regarding this ratio is different.

\section{Correlation Analysis}

\section{Correlation between CRAR and Interest Income}

The industry correlation is 0.6385 which is significantly positive though DFI's correlation is negative. So, we can say that as increased CRAR positively correlated with interest income and it is possible for increasing the capital base which reduces the interest expenses to the depositors.

\section{Correlation between NPL to Loans Ratio and Interest income}

Figure 5.19 show that there exists negative correlation between NPL to loan and interest income. As NPL to loan ratio decreases, interest income increases and the correlation between this two criteria is -.9622 for the industry as a whole over the period. So, we can say that Banks should emphasize on reducing the NPL.

\subsection{Conclusion}

An efficient operation of banking sector enables the smooth financial resources intermediation of an economy. Economic growth is contributed greatly by the efficiency of banking sector in resources generation and its proper allocation. The smooth and efficient operation of banking sector also helps to reduce risk of failure of an economy. Therefore, the performance of 
banking sector is always been a source of interest for researchers to judge the economic condition of a country. Regulators of the banking sector always monitors the performance of the banks to ensure efficient financial system based on CAMEL ratio.

Among the entire CAMEL ratio, some important ratios which are most significant are analyzed to judge the performance of the banking industry in Bangladesh. Among the four categories of banks operating in Bangladesh, DFIs has been found more vulnerable compared to the rest of three categories. CRAR, NPL to total loan, EIR all are too high and provision maintenance ratio, ROA, ROE, liquidity ratio is too low in DFIs and this scenario also reflects negatively in overall banking industry performance of Bangladesh. FCBs shows and PCBs show all the positive signal of well functioning whereas SCBs also shows a trend of improving performance.

\section{References}

Ahmed, F. (1995) Performance of Commercial Banks in Bangladesh-A Note on Current trends. Journal of the Institute of Bankers, Bangladesh. Vol. 36 -41, December 1992-June 1995.

Bangladesh Bank Annual Report, (2004-2011), (www.bangladesh-bank.org)

Bangladesh Bank Manual for Ratio Analysis and CAMEL Rating System (2006), http://ncalculators.com/statistics/correlation-coefficient-calculator.htm

C, D, Parimal. K, G, Badal. Hasan Tuhin, Mehedi Financial Performance in Banking Sector in Bangladesh: A Comparative Study of Some Selected Private Commercial Banks. Journal of Banking \& Financial Services, Department of Banking Faculty of Business Studies University of Dhaka. Vol. 5 Number 1 July 2011

Chowdhury, A. (2002), "Politics, Society and Financial Sector Reform in Bangladesh", International Journal of Social Economics, 29(12), 963-988.

Chowdhury, H. A., \& Islam, M. S. (2007), "Interest sensitivity of loans and advances: A competitive study between nationalized commercial banks and specialized commercial banks", ASA University review, 1(1), 124-141.

Chowdhury, T. A., \& Ahmed, K. (2009), "Performance Evaluation of Selected Commercial Banks in Bangladesh", International Journal of Business and Management, 4(4), 86-97.

Khan, A. R. (2009), "Sources and uses of funds, performance evaluation and bank failure", Bank Management: A fund Emphasis, (2nd edition), Dhaka: Decent Book House, pp. 51-68.

Mujeri, M. K., \& Younus, S. (2009), “An analysis of interest rate spread in banking sector in Bangladesh", The Bangladesh Development Studies, 32(4), 65-89

Pandey I. M. (2004), "Financial statement analysis", Financial Management, (9th edition). New Delhi, India: Vikas, pp. 517-558.

Van Horne J. C. \& Wachowicz Jr. J. M. (2005), "Financial statement analysis", Fundamentals of Financial Management, (11th edition). India, Pearson, pp. 125-168. 


\section{Copyright Disclaimer}

Copyright reserved by the author(s).

This article is an open-access article distributed under the terms and conditions of the Creative Commons Attribution license (http://creativecommons.org/licenses/by/3.0/). 